\title{
Protection of metals in phosphoric acid solutions by corrosion inhibitors. A review
}

\author{
Ya.G. Avdeev \\ A.N. Frumkin Institute of Physical Chemistry and Electrochemistry, Russian Academy of \\ Sciences, Leninskii pr. 31, Moscow, 119071 Russian Federation \\ *E-mail: avdeevavdeev@mail.ru
}

\begin{abstract}
The article summarizes the literature data and patents on the protection of steels and nonferrous metals in phosphoric acid solutions with various corrosion inhibitors. Some aspects of practical use of $\mathrm{H}_{3} \mathrm{PO}_{4}$ solutions, their properties and corrosivity toward various metals are reviewed. It is shown that the overwhelming majority of individual organic and inorganic compounds, as well as composite inhibitors offered for the protection of metals in this medium are of low efficiency due to weak adsorption on metal surfaces. A promising method for the protection of steels in phosphoric acid media involves the use of formulations containing triazole derivatives and sulfur-containing additives. The components of these mixtures form polymolecular protective layers on the metal surface that are highly efficient in slowing down corrosion processes even at temperatures up to $100^{\circ} \mathrm{C}$. An important property of these protective layers is a strong chemical bond of the inhibitor molecules with the metal surface and with each other inside the layer. Inhibited $\mathrm{H}_{3} \mathrm{PO}_{4}$ solutions resistant to the accumulation of corrosion stimulators - Fe(III) salts - may become a new and promising field of use for this acid. The bibliographic list includes 170 sources.
\end{abstract}

Keywords: corrosion inhibitors, acid corrosion, phosphoric acid, orthophosphoric acid, steels, nonferrous metals, triazoles.

Received: July 20, 2019. Published: September 27, 2019

doi: $\underline{10.17675 / 2305-6894-2019-8-4-1}$

\section{Introduction}

Solutions of orthophosphoric (hereinafter referred to as phosphoric) acid $\mathrm{H}_{3} \mathrm{PO}_{4}$, along with other mineral acids, are in use in modern industries for removal of heat scale, rust, limescale, and other mineral deposits from steel surfaces. $\mathrm{H}_{3} \mathrm{PO}_{4}$-based formulations are used for the treatment of petroleum and gas reservoirs from carbonate deposits [1].

Back in the beginning of the XX century, U.R. Evans [2], who discussed various aspects of acid etching of steels, considered $\mathrm{H}_{3} \mathrm{PO}_{4}$ solutions as an alternative to inhibited solutions of hydrochloric and sulfuric acids. He stated that $\mathrm{H}_{3} \mathrm{PO}_{4}$ excelled those acids since its traces remaining on the metal caused no corrosion due to weak solubility of iron phosphates that build up a protective film. It was stated as a drawback that at a normal temperature, etching in $\mathrm{H}_{3} \mathrm{PO}_{4}$ was slow and it was necessary to heat solutions to $85^{\circ} \mathrm{C}$, 
which sometimes was inconvenient. Nevertheless, the method was considered valuable, especially when a thorough rinsing after etching was difficult. According to Evans, this method was approved by the Dutch Corrosion Committee and recommended by Büttner <author's remark: G. Büttner, Korr. Met., 1931, 7, 251>, who found that the use of inhibitors could be avoided in $\mathrm{H}_{3} \mathrm{PO}_{4}$ and that iron phosphate remaining on the metal gave a very good primer for painting. After etching in $\mathrm{H}_{2} \mathrm{SO}_{4}$ and $\mathrm{HCl}$ solutions, steel parts are often submerged in dilute $\mathrm{H}_{3} \mathrm{PO}_{4}$ for a short time. Such samples behave better after painting than those treated in $\mathrm{H}_{2} \mathrm{SO}_{4}$ or $\mathrm{HCl}$.

The nonvolatile phosphoric acid allows the process of steel etching to be intensified without special material costs through increasing the temperature. Analysis of literature data [3] shows that, all other things being equal, hydrogenation of steels is much weaker in $\mathrm{H}_{3} \mathrm{PO}_{4}$ solutions than in $\mathrm{H}_{2} \mathrm{SO}_{4}$ and $\mathrm{HCl}$. The high speed of heat scale removal from the surface of low-carbon steel in $\mathrm{H}_{3} \mathrm{PO}_{4}$ solutions is comparable with that in $\mathrm{HCl}$ solutions and considerably exceeds sulfuric acid media $[4,5]$. In $1 \mathrm{~N}$ acid solutions it exceeds $\mathrm{HCl}$, $\mathrm{H}_{2} \mathrm{SO}_{4}, \mathrm{HNO}_{3}$ and $\mathrm{HClO}_{4}$ in the rate of dissolving iron(III) oxide, being inferior only to $\mathrm{HF}$ [6].

Phosphoric acid demonstrates low reactivity toward various rocks built by calcium carbonate in comparison to $\mathrm{HCl}$ and $\mathrm{HNO}_{3}$ [1]. For example, at $20^{\circ} \mathrm{C}$ the rate of the reaction of $5-50 \% \mathrm{H}_{3} \mathrm{PO}_{4}$ with marble is $1-2 \mathrm{~g} /\left(\mathrm{m}^{2} \cdot \mathrm{h}\right)$. The maximum rate occurs in the acid concentration range of $20-45 \%$, while the dissolution stops at a mass percent of the acid $\omega_{\mathrm{H} 3 \mathrm{PO} 4}>60 \%$.

Phosphoric acid has the form of crystals with a density of $1870 \mathrm{~kg} / \mathrm{m}^{3}\left(20^{\circ} \mathrm{C}\right)$. It mixes with water in any ratio with exponential variation of viscosity and density, is nontoxic and has no oxidizing properties [1]. $\mathrm{H}_{3} \mathrm{PO}_{4}$ is a strong acid in aqueous solutions ${ }^{*}$ $\left(\mathrm{p} K_{\mathrm{aI}}=2.12, \mathrm{p} K_{\mathrm{aII}}=7.20, \mathrm{p} K_{\mathrm{aIII}}=12.32\right)$. Dissociation by the first stage is exothermic but endothermic by the second and third stages [8]. It is considered that aqueous $\mathrm{H}_{3} \mathrm{PO}_{4}$ solutions $(0.1-10 \mathrm{~mol} / \mathrm{kg})$ may involve the following ion-molecular equilibria with participation of both monomeric and dimeric molecular forms [9]:

$$
\begin{gathered}
\mathrm{H}_{3} \mathrm{PO}_{4}=\mathrm{H}^{+}+\mathrm{H}_{2} \mathrm{PO}_{4}^{-}, \\
\mathrm{H}_{2} \mathrm{PO}_{4}^{-}+\mathrm{H}_{3} \mathrm{PO}_{4}=\mathrm{H}_{5} \mathrm{P}_{2} \mathrm{O}_{8}^{-}, \\
\mathrm{H}_{6} \mathrm{P}_{2} \mathrm{O}_{8}=\mathrm{H}^{+}+\mathrm{H}_{5} \mathrm{P}_{2} \mathrm{O}_{8}^{-} .
\end{gathered}
$$

This is confirmed by the experimental data on vapor pressure, electric conductivity, $\mathrm{pH}$ and osmotic pressure measurements in aqueous acid solutions, as well as by the results of their studies by Raman spectroscopy.

Reference data on the corrosion resistance of various metals and alloys in $\mathrm{H}_{3} \mathrm{PO}_{4}$ and its solutions under diverse conditions are summarized in the reference book [10]. It should

\footnotetext{
* Some authors [1] attribute $\mathrm{H}_{3} \mathrm{PO}_{4}$ to medium-strength or even weak acids [7].
} 
be noted that under certain conditions, such media are rather corrosive to metallic materials. Solutions of $\mathrm{H}_{3} \mathrm{PO}_{4}$ itself, especially when heated, actively react with contacting steels, which is contrary to U.R. Evans' concept on the possibility of replacing inhibited inorganic acids with phosphorus acid [2]. For example, the corrosion rate $(k)$ of St3 steel (content in mass percent, \%: 0.14-0.22 C, 0.05-0.17 Si, 0.40-0.65 Mn, up to $0.30 \mathrm{Ni}$, up to $0.30 \mathrm{Cu}$, up to $0.30 \mathrm{Cr}$, up to $0.08 \mathrm{As}$, up to $0.05 \mathrm{P}$, up to $0.05 \mathrm{~S}$, balance $\mathrm{Fe}$ ) in $2 \mathrm{M}$ $\mathrm{H}_{3} \mathrm{PO}_{4}\left(0-95^{\circ} \mathrm{C}\right)$ is from 2.4 to $520 \mathrm{~g} /\left(\mathrm{m}^{2} \cdot \mathrm{h}\right)$. A growth in acid concentration $(C)$ in the solution $\left(60^{\circ} \mathrm{C}\right)$ from 1 to $8 \mathrm{M}$ accelerates corrosion from 29 to $190 \mathrm{~g} /\left(\mathrm{m}^{2} \cdot \mathrm{h}\right)$ [11]. Similar trends in the behavior of low-carbon steels were found elsewhere [12-15]. Alloyed nickel-chromium steels containing $17-23 \% \mathrm{Cr}$ and $6-28 \% \mathrm{Ni}$ are more resistant to $\mathrm{H}_{3} \mathrm{PO}_{4}$. In solutions with $\omega_{\mathrm{H} 3 \mathrm{PO} 4} \leq 20 \%$, the $k$ values of these acids at $150^{\circ} \mathrm{C}$ are $\leq 1 \mathrm{~g} /\left(\mathrm{m}^{2} \cdot \mathrm{h}\right)$ according to the data of 8-hour testing, and some steels maintain resistance to corrosion even at $200^{\circ} \mathrm{C}$ [15]. However, E.V. Filimonov et al. [16, 17] found that nickelchromium steel X18H10T (content in mass percent, \%: $0.11 \mathrm{C}, 9.66 \mathrm{Ni}$; $18.66 \mathrm{Cr}, 0.57 \mathrm{Ti}$, remainder $\mathrm{Fe})$ in $\mathrm{H}_{3} \mathrm{PO}_{4}\left(100-150^{\circ} \mathrm{C}\right)$ may be in an unstable passive state where several similar samples present in an absolutely the same corrosion medium are destroyed at rates differing by more than an order of magnitude. The maximum corrosion rate of the samples $(k)$ reaches tens of $\mathrm{g} /\left(\mathrm{m}^{2} \cdot \mathrm{h}\right)$. Special issues of stability of steel structures in $\mathrm{H}_{3} \mathrm{PO}_{4}$ during its manufacturing are addressed in $[18,19]$.

The importance of phosphoric acid in modern industries, as well as the high corrosivity of its hot solutions to steels makes it necessary to critically analyze the literature on the methods of inhibitor protection of metals and alloys in this environment and find its physicochemical regularities. The presence of efficient inhibitors for phosphoric acid environments is important in practical terms, because it expands the application fields of $\mathrm{H}_{3} \mathrm{PO}_{4}$ by lowering its corrosivity towards various process equipment that it may contact.

General issues of inhibitor protection of metals and alloys in aqueous media, as well as the specifics of the mechanism of action of various groups of metal corrosion inhibitors (CI) in these media are addressed in the monograph [20] and reviews [21-27]. However, these studies provide no detailed examination of the specifics of using CI for the protection of metals in acid solutions.

The protection of metals by corrosion inhibitors in acid solutions was considered most thoroughly in monographs $[28,29]$ and review [30], but more than 30 years have passed since they were published. A number of reviews dedicated to some special groups of CIs in acids, such as unsaturated organic compounds [31], acetylenic compounds [32], unsaturated carbonyl compounds [33], azomethines [33,34], N-containing six-membered organic heterocycles $[35,36]$, as well as the specifics of their mechanism of protective action, have been published in the recent 15 years.

Reviews [37, 38] describe the protective properties of CIs recommended for oil and gas industry. Reference data are contained in articles stated to be reviews, which are 
dedicated to the effect of organic CIs on the electrochemical behavior of steels in acid solutions [39] or to reviewing separate CI groups: formulations of organic compounds with halide anions [40], derivatives of thiocarbamide and thiadiazole [41], polymer compounds [42], pharmaceuticals [43], amino acids [44], ecologically pure products [45], vegetal extracts [46]. Data on the protection of aluminum alloys in $\mathrm{HCl}$ and $\mathrm{H}_{2} \mathrm{SO}_{4}$ solutions are collected and summarized in [47]. Only two special reviews [48, 49] study the issues of inhibitor protection of metals in phosphoric acid.

In spite of the big number of reviews dedicated to CIs of metals for acid media, the emphasis in these studies is put on considering the issues concerning the protection of metals in $\mathrm{HCl}$ and $\mathrm{H}_{2} \mathrm{SO}_{4}$ solutions as the most important ones in practical terms. The problem of inhibitor protection of metals in phosphoric acid media lacked proper attention, though its solution is a complex practical task. Many CIs that efficiently protect metals in $\mathrm{HCl}$ and $\mathrm{H}_{2} \mathrm{SO}_{4}$ solutions are unfit for protection of metals in $\mathrm{H}_{3} \mathrm{PO}_{4}$. In spite of the fact that reviews $[48,49]$ were published just recently, today they incompletely in cover the actual state of inhibitor protection of metals in $\mathrm{H}_{3} \mathrm{PO}_{4}$ solutions in many respects. From our point of view, some new, principally important results have been obtained in this field of CI science in recent years. A new theoretically founded trend discussed in the article includes the issues of creating inhibited $\mathrm{H}_{3} \mathrm{PO}_{4}$-based solutions resistant to the accumulation of strong corrosion stimulators, Fe(III) salts, in these solutions.

Therefore, groups of compounds promising as CIs for phosphoric acid media that comply with process and environmental requirements of present-day industries should be determined. Understanding the specifics in mechanism of action of such compounds that determine the high quality of metal protection in $\mathrm{H}_{3} \mathrm{PO}_{4}$ solutions is very important.

\section{Assortment of corrosion inhibitors for phosphoric acid solutions}

The most complete information on successful use of CIs for protection of metals in phosphoric acid media under modern industrial conditions may be obtained by analyzing the assortment of CIs used at various industrial plants. We will carry out the analysis of the assortment of industrial CIs for phosphoric acid media by the example of industrial plants of the Russian Federation. In the USSR, a wide variety of acid corrosion inhibitors represented by more than 30 marketable product titles [28, 29, 50, 51] were developed and produced. The vast majority of them are toxic derivatives of pyridine and quinoline and do not comply with tough process and sanitary requirements of the modern industries. In addition, owing to economic reasons the production of many of these products was stopped or considerably reduced to date. Analysis of the list of corrosion inhibitors used in the USSR shows that only some of them, viz., PKU-3, PKU-3R, OB-1, OR-2, KhOD-4, KhOSP-10 and S-5U, are suitable for inhibiting the corrosion of steels in $\mathrm{H}_{3} \mathrm{PO}_{4}$ solutions (Table 1). The composition of PKU-3R and OR-2 inhibitors includes ammonium rhodanide as a synergistic additive $[29,52]$. To improve the protective action of PKU-M inhibitor that is inefficient on steel 10 in $4 \mathrm{~N} \mathrm{H}_{3} \mathrm{PO}_{4}$, addition of sodium dithiocarbamate 
[53] is recommended. For example, adding $0.3 \mathrm{~g} / \mathrm{l}$ sodium dithiocarbamate at $t=60-80^{\circ} \mathrm{C}$ to the solution increases the inhibition coefficient $(\gamma)$ of $3 \mathrm{~g} / \mathrm{l}$ PKU-M 8.6-14.4 fold.

Table 1. Assortment of metal acid corrosion inhibitors produced in the USSR and recommended for $\mathrm{H}_{3} \mathrm{PO}_{4}$ solutions [29, 52].

\begin{tabular}{|c|c|c|c|}
\hline $\begin{array}{l}\text { Inhibitor } \\
\text { name }\end{array}$ & Chemical composition & $\begin{array}{l}\text { Application } \\
\text { medium }\end{array}$ & Protected metal \\
\hline PKU-3 & $\begin{array}{l}\text { Urotropine and benzyl chloride } \\
\text { condensation products }\end{array}$ & $\begin{array}{l}4 \mathrm{~N} \mathrm{H}_{3} \mathrm{PO}_{4} \\
\left(t=80^{\circ} \mathrm{C}\right)\end{array}$ & $\begin{array}{c}\text { Steel 10, } \\
\gamma=90(5 \mathrm{~g} / \mathrm{l})\end{array}$ \\
\hline PKU-3R & $\begin{array}{l}\text { Mixture of } 95 \% \text { PKU-3 and } 5 \% \\
\text { ammonium rhodanide }\end{array}$ & $\begin{array}{c}4 \mathrm{~N} \mathrm{H}_{3} \mathrm{PO}_{4} \\
\left(t=80^{\circ} \mathrm{C}\right)\end{array}$ & $\begin{array}{c}\text { Steel } 10, \\
\gamma=112(5 \mathrm{~g} / \mathrm{l})\end{array}$ \\
\hline OB-1 & $\begin{array}{l}\text { Composite of substituted ammonium } \\
\text { salts, an organobromine compound } \\
\text { and a foam maker }\end{array}$ & $\begin{array}{c}4 \mathrm{~N} \mathrm{H}_{3} \mathrm{PO}_{4} \\
\left(t=30-85^{\circ} \mathrm{C}\right)\end{array}$ & $\begin{array}{c}\text { Steel St3 } \\
\gamma=95-246(1.5 \mathrm{~g} / \mathrm{l})\end{array}$ \\
\hline OR-2 & $\begin{array}{l}\text { Product of reaction of quinoline bases, } \\
\text { benzyl chloride and ammonium } \\
\text { rhodanide. Efficient agent }-20 \% \\
\text { benzylquinolium rhodanide) }\end{array}$ & $\mathrm{H}_{3} \mathrm{PO}_{4}$ & Carbon steel \\
\hline KhOD-4 & $\begin{array}{l}\text { Composite containing substituted } \\
\text { ammonium salts }\end{array}$ & $\begin{array}{c}4 \mathrm{~N} \mathrm{H}_{3} \mathrm{PO}_{4} \\
\left(t=30-85^{\circ} \mathrm{C}\right)\end{array}$ & $\begin{array}{c}\text { Steel 10, } \\
Z=97.2-99.2 \%(2 \mathrm{~g} / \mathrm{l})\end{array}$ \\
\hline KhOSP-10 & $\begin{array}{l}\text { Mixture of quaternary ammonium } \\
\text { salts, foam maker and synergist }\end{array}$ & $\begin{array}{c}6 \mathrm{M} \mathrm{H}_{3} \mathrm{PO}_{4} \\
\left(t=30-90^{\circ} \mathrm{C}\right)\end{array}$ & $\begin{array}{c}\text { Steel } 20 \\
\gamma=8-102(1.5 \mathrm{~g} / \mathrm{l}) \\
\text { Steel } 40 \mathrm{X} \\
\gamma=38-194(1.5 \mathrm{~g} / \mathrm{l})\end{array}$ \\
\hline S-5U & $\begin{array}{l}\text { Modified waste of cake and by- } \\
\text { product production. }\end{array}$ & $\begin{array}{l}2 \mathrm{~N} \mathrm{H}_{3} \mathrm{PO}_{4} \\
\left(t=50^{\circ} \mathrm{C}\right)\end{array}$ & $\begin{array}{c}\text { Steel St3, } \\
\gamma=13(2.5 \mathrm{~g} / 1)\end{array}$ \\
\hline
\end{tabular}

To date, the assortment of inhibitors of acid corrosion for metals used in the industries of the Russian Federation has been renewed considerably. In TNK-BP enterprises, 12 such domestic inhibitors [54] are reportedly used, but the possibility of using them in $\mathrm{H}_{3} \mathrm{PO}_{4}$ solutions is not mentioned. To protect steel in hydrochloric acid media in oil and gas sector enterprises, CIs of Aquatec-50 series (manufactured by NPO "Aquatec") [55] are recommended. The possibility of using them in $\mathrm{H}_{2} \mathrm{SO}_{4}$ and $\mathrm{H}_{3} \mathrm{PO}_{4}$ solutions is mentioned, but information on the protective effects of the CIs is not provided.

A comprehensive study [56] of the protective properties of a series of CIs (Soling $\mathrm{m}$. Z, Soling $\mathrm{m}$. L, VNPP-2, INVOL-2 m. A, NORUST CM $150 \mathrm{C}$ ) used in oil and gas sector enterprises proved their low efficiency in inhibiting corrosion of steels in $\mathrm{H}_{3} \mathrm{PO}_{4}$ solutions, although in $\mathrm{HCl}$ solutions they slowed down the corrosion well. For example, in 
$2 \mathrm{M}$ of $\mathrm{H}_{3} \mathrm{PO}_{4}\left(20-100^{\circ} \mathrm{C}\right)$ for the studied CIs the maximum decrease in $k$ for 08PS steel (content in mass percent, \%: $0.08 \mathrm{C}, 0.5 \mathrm{Mn}, 0.11 \mathrm{Si}, 0.035 \mathrm{P}, 0.04 \mathrm{~S}, 0.1 \mathrm{Cr}, 0.25 \mathrm{Ni}, 0.25$ $\mathrm{Cu}, 0.08 \mathrm{As}$, remainder $\mathrm{Fe}$ ) was 5.4 -fold. These $\mathrm{CIs}$ are equally inefficient in the protection of 70S2KhA high-strength steel (content in mass percent, \%: $0.7 \mathrm{C}, 0.52 \mathrm{Mn}, 1.52 \mathrm{Si}$, $0.3 \mathrm{Cr}$, remainder $\mathrm{Fe})$. In $2 \mathrm{M} \mathrm{H}_{3} \mathrm{PO}_{4}\left(20^{\circ} \mathrm{C}\right)$ the biggest decrease in $k$ of this steel is 4-fold, while the maximum steel plasticity remains at $\sim 64 \%$, which indicates its strong hydrogenation.

The above data show the actual lack of commercially produced CIs suitable for the protection of metals in $\mathrm{H}_{3} \mathrm{PO}_{4}$ solutions. Only some of them can provide metal protection in $\mathrm{H}_{3} \mathrm{PO}_{4}$ after modification with additives. All these facts show the relevance of searching CIs for such media.

Many organic compounds (acetylene derivatives [57], azomethines [58], quaternary ammonium salts (QAS) and N-containing heterocycles [59]) that efficiently inhibit corrosion of steels in $\mathrm{HCl}$ solutions and in some cases in $\mathrm{H}_{2} \mathrm{SO}_{4}$, poorly inhibit it in $\mathrm{H}_{3} \mathrm{PO}_{4}$ solutions. For example, the $\gamma$ of propargyl chloride for $\mathrm{St} 3$ steel at $25^{\circ} \mathrm{C}$ in $2 \mathrm{M} \mathrm{HCl}$ and $\mathrm{H}_{2} \mathrm{SO}_{4}$ is 10.9 and 18.5 times higher than in $2 \mathrm{M} \mathrm{H}_{3} \mathrm{PO}_{4}$ [57]. This results from the reduction of propargyl chloride on steel in $\mathrm{H}_{3} \mathrm{PO}_{4}$ that facilitates the cathodic process. Sometimes an increase in $\mathrm{H}_{3} \mathrm{PO}_{4}$ content in solution may lead to a substantial protective action of an organic compound. For example, $5 \mathrm{mM}$ of catamine $\mathrm{AB}$ at $C\left(\mathrm{H}_{3} \mathrm{PO}_{4}\right)=1-6 \mathrm{M}$ at $60^{\circ} \mathrm{C}$ inhibits corrosion of St3 steel no more than 7.2 -fold. Under the same conditions, the $\gamma$ provided by catamine $\mathrm{AB}$ in $8 \mathrm{M} \mathrm{H}_{3} \mathrm{PO}_{4}$ is 32.1 [59].

Numerous compounds considered by the authors as CIs of steels in $\mathrm{H}_{3} \mathrm{PO}_{4}$ solutions are described in scientific literature. However, from our point of view, this information requires a critical analysis. For example, a group of Kenyan researchers [60] recommend to protect $\mathrm{C} 35 \mathrm{E}$ carbon steel (content in mass percent, \%: $0.370 \mathrm{C}, 0.230 \mathrm{Si}, 0.680 \mathrm{Mn}, 0.016$ $\mathrm{S}, 0.077 \mathrm{Cr}, 0.011 \mathrm{Ti}, 0.059 \mathrm{Ni}, 0.009 \mathrm{Co}, 0.160 \mathrm{Cu}$, remainder $\mathrm{Fe}$ ) in $2 \mathrm{M}$ of $\mathrm{H}_{3} \mathrm{PO}_{4}$ (at $30^{\circ} \mathrm{C}$ ) with the additive N-1-naphthylethylenediamine dihydrochloride, which at high $C=$ $0.01 \mathrm{M}$ only provides $Z=88.1 \%$. The same poor efficiency in $1 \mathrm{M}^{\circ} \mathrm{H}_{3} \mathrm{PO}_{4}$ is shown by benzimidazole (BI) and its 2-substituted derivatives, the most efficient of which, 2-aminoBI, inhibits the corrosion of mild steel 3.3-fold at $C=5 \mathrm{mM}$ [61]. Somewhat better results are shown by 3,5-bis( $N$-pyridyl)-4-amino-1,2,4-triazoles with various structures that provide $Z=92-93 \%$ in $3 \mathrm{M} \mathrm{H}_{3} \mathrm{PO}_{4}\left(\right.$ at $30^{\circ} \mathrm{C}$ ) at $C_{\text {in }}=0.1 \mathrm{mM} \mathrm{[62].}$

Many organic compounds are satisfactory in protecting various steels in cold $\mathrm{H}_{3} \mathrm{PO}_{4}$, but heating reduces the protective action of CIs. The toxic benzyltriphenylphosphonium chloride $(C=1 \mathrm{mM})$ in $0.3 \mathrm{M} \mathrm{H}_{3} \mathrm{PO}_{4}$ at $25^{\circ} \mathrm{C}$ provides $Z=94 \%$, but increasing the $t$ of the solution by $40^{\circ} \mathrm{C}$ decreases $Z$ to $85 \%$ [63]. Quaternary salts of pyridinium and quinolinium (1-methyl-4[4' $\left(-\mathrm{N}\left(\mathrm{CH}_{3}\right)_{2}\right)$-styryl]pyridinium iodide (QI), 1-methyl-4[4' $\left(-\mathrm{N}\left(\mathrm{CH}_{3}\right)_{2}\right)$ styryl]quinolinium iodide (QII), 1-methyl-4[4'(-OCH$\left.)_{3}\right)$-styryl]quinolinium iodide (QIII)) were studied as corrosion inhibitors of mild steel (content in mass percent, \%: $0.02 \mathrm{P}, 0.37$ $\mathrm{Mn}, 0.03 \mathrm{~S}, 0.01 \mathrm{Mo}, 0.039 \mathrm{Ni}, 0.21 \mathrm{C}$, remainder $\mathrm{Fe}$ ) in $2 \mathrm{M} \mathrm{H}_{3} \mathrm{PO}_{4}$ (at $30^{\circ} \mathrm{C}$ ). The most 
efficient of them, QIII, provides $Z=99.95 \%$ at $C_{\text {in }}=0.5 \mathrm{mM}$. The protective action of the CIs decreases in the series: QIII $>$ QII $>$ QI. Increasing $t$ to $70^{\circ} \mathrm{C}$ decreases $Z_{\text {QIII }}$ to $73.01 \%$ [64]. 1-Dodecyl-5-methyl-1H-benzo[d][1,2,3]triazol-1-ium bromide was studied as a CI of carbon steel (content in mass percent, \%: $0.28 \mathrm{C}, 0.06 \mathrm{Ti}, 1.40 \mathrm{Mn}, 0.03 \mathrm{P}, 0.03 \mathrm{~S}$, remainder $\mathrm{Fe}$ ) in $7 \mathrm{M} \mathrm{H}_{3} \mathrm{PO}_{4}$ by gravimetry, voltammetry and electrochemical impedance spectroscopy (EIS) methods with similar results. As stated above, the protective action of organic CIs in $\mathrm{H}_{3} \mathrm{PO}_{4}$ solutions with high concentration of the latter is good, but even in this case, the $Z$ value of this CI determined by gravimetric measurements decreases from 97.2 to $87.8 \%$ with a $t$ increase from 20 to $80^{\circ} \mathrm{C}$ [65]. The Sulfapyridine drug [66] also loses its protective action toward C35E carbon steel (content in mass percent, \%: $0.370 \mathrm{C}$, $0.230 \mathrm{Si}, 0.680 \mathrm{Mn}, 0.016 \mathrm{~S}, 0.077 \mathrm{Cr}, 0.011 \mathrm{Ti}, 0.059 \mathrm{Ni}, 0.009 \mathrm{Co}, 0.160 \mathrm{Cu}$ remainder $\mathrm{Fe}$ ) in $2 \mathrm{M} \mathrm{H}_{3} \mathrm{PO}_{4}$ with an increase in $t$. According to the results of similar studies on mild steel (content in mass percent, \%: $0.017 \mathrm{C}, 0.007 \mathrm{Si}, 0.196 \mathrm{Mn}, 0.014 \mathrm{~S}, 0.043 \mathrm{Cr}, 0.013$ $\mathrm{Ni}, 0.015 \mathrm{Mo}, 0.196 \mathrm{Mn}$, remainder $\mathrm{Fe}$ ), $5 \%$ morpholine at $30^{\circ} \mathrm{C}$ in $2 \mathrm{~N} \mathrm{H}_{3} \mathrm{PO}_{4}$ provides $Z=96.9 \%$, and in $2 \mathrm{~N} \mathrm{H}_{2} \mathrm{SO}_{4}$ it is only $68.5 \%$. However, at $60^{\circ} \mathrm{C}$ the $Z$ values are $74.7 \%$ and 78.4, accordingly [67]. A similar situation is observed in the protection of mild steel with folic acid in $0.5 \mathrm{M} \mathrm{H}_{3} \mathrm{PO}_{4}$ [68].

The "environment-friendly" inhibitors specially developed for phosphoric acid media,

such as barbiturates:

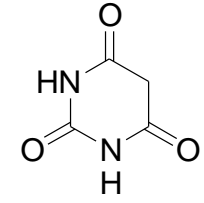

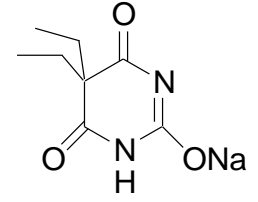

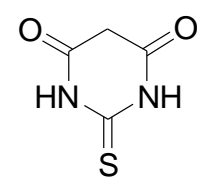

[69], natural monoterpenphenol

(2-isopropyl-5-methylphenol) [70], absinth oil [71], apricot juice [72], extracts of plants Acalypha indica L. [73] and Plectranthus Amboinius L. [74], extract of bamboo leaves and

its components (rutin


[75], as well as

alcoholic extract of guayaba leaves [76], are poor inhibitors of mild steel corrosion. Even at ambient $t$ these CIs in $0.1-2 \mathrm{M} \mathrm{H}_{3} \mathrm{PO}_{4}$ do not provide $Z>90 \%$ for mild steels.

A better protection of carbon and even highly alloyed steels in phosphoric acid solutions at ambient $t$ is provided by adding relatively hydrophobic S-containing compounds: L-cysteine methyl ester hydrochloride [77], allylthiourea [78], thiosemicarbazide and its derivatives [79], 1-benzoyl-4-phenyl-3-thiosemicarbazide [80], 4-(N,N-diethylamino)benzaldehydethiosemicarbazone [81], 3,4-dimethoxybenzaldehydethiosemicarbazone [82], 2-mercapto-BI [83], 2-mercaptothiazoline [84], 2mercaptopyrimidine [85], benzothiazole derivatives 


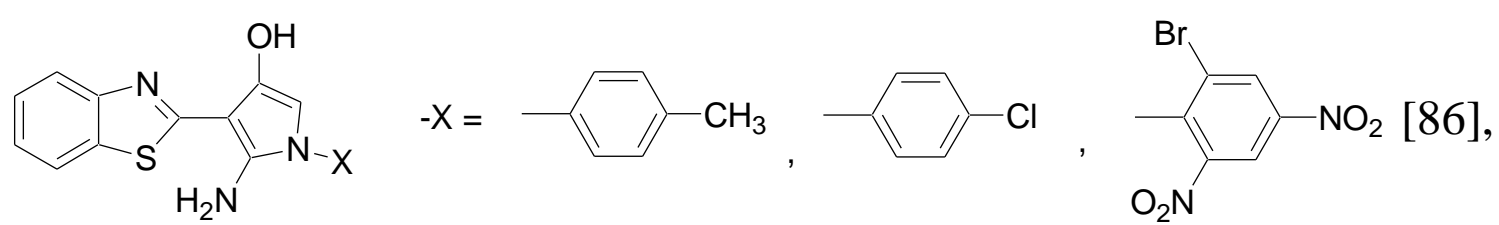

4-amino-3-hydrazino-5-mercapto-1,2,4-triazole [87], 3-phenyl-4-amino-5-mercapto-1,2,4triazole [88], thiophene derivative amino-3-hydrazino-5-mercapto-1,2,4-triazole [87] in $2 \mathrm{M} \mathrm{H}_{3} \mathrm{PO}_{4}$ (at $30^{\circ} \mathrm{C}$ ) on $\mathrm{C} 35 \mathrm{E}$ carbon steel at $C=0.01 \mathrm{M}$ provides $Z=96.8 \%$. However, with increasing $t$, S-containing compounds ( $L$-cysteine methyl ester hydrochloride, 4-( $N, N$-diethylamino)benzaldehydethiosemicarbazone, 3,4-dimethoxybenzaldehydethiosemicarbazone, 4-amino3-hydrazino-5-mercapto-1,2,4-triazole, thiophene derivative) inhibit corrosion of steels more poorly. For example, for 4-amino-3-hydrazino-5-mercapto-1,2,4-triazole an increase in $t$ from 30 to $50^{\circ} \mathrm{C}$ decreases $\gamma 15$-fold [87]. An exclusion here is allylthiourea whose protective action increases somewhat with a $t$ increase from 30 to $50^{\circ} \mathrm{C}$ [78]. Not all Scontaining compounds (thiourea [90], 1,2-bis(thiophen-2-ylidenemethyl)hydrazine [91], 4substituted phenacyldimethylsulfonium bromide [93] and Alizarin red ambient temperature.

Unsuccessful attempts to create $\mathrm{CIs}$ for $\mathrm{H}_{3} \mathrm{PO}_{4}$ with the use of acetylacetonate complexes of $\mathrm{Co}(\mathrm{II}), \mathrm{Cu}(\mathrm{II}), \mathrm{Zn}(\mathrm{II}), \mathrm{Mn}(\mathrm{II})$ [94], ruthenium complex

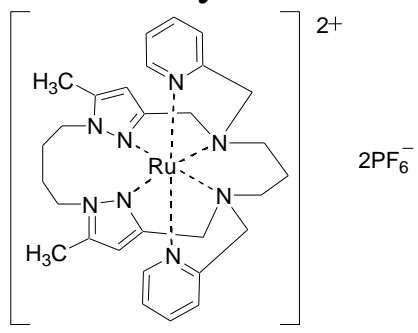

[95]) and inorganic compounds (aluminum phosphate [96]) were also undertaken.

Addition of $\mathrm{Cu}(\mathrm{II})$ cations obtained by dissolving $\mathrm{CuO}$ in $\mathrm{H}_{3} \mathrm{PO}_{4}$, or $\mathrm{NO}_{3}^{-}$anions in the form of $\mathrm{NaNO}_{3}$ is recommended to protect X18H10T chromium-nickel steel in hot $\mathrm{H}_{3} \mathrm{PO}_{4}$ solutions (up to $130^{\circ} \mathrm{C}$ ). The mechanism of action of these additives that favor the existence of chromium-nickel steel in $\mathrm{H}_{3} \mathrm{PO}_{4}$ solutions in the passive state was studied [97, 98].

Under conditions of specific corrosion-abrasive wear of an austenitic chromiumnickel steel (content in mass percent, \%: $26.75 \mathrm{Cr}, 31.43 \mathrm{Fe}, 31.85 \mathrm{Ni}, 6.6 \mathrm{Mo}, 1.5 \mathrm{Mn}$, $1.21 \mathrm{Cu}, 0.193 \mathrm{~N}, 0.1 \mathrm{Si}, 0.005 \mathrm{C}, 0.002 \mathrm{~S}, 0.017 \mathrm{P})$ in $40 \% \mathrm{H}_{3} \mathrm{PO}_{4}+4 \% \mathrm{H}_{2} \mathrm{SO}_{4}+0.42 \%$ 
$\mathrm{KCl}$ containing a $\mathrm{SiC}$ abrasive $(24 \mathrm{~g} / \mathrm{l}$, angle of impact of abrasive particles on the surface $90^{\circ}$ ), addition of $6 \mathrm{~g} / \mathrm{l}$ clay (content in mass percent, \%: $38.86 \mathrm{SiO}_{2}, 10.76 \mathrm{Al}_{2} \mathrm{O}_{3}, 16.48$ $\mathrm{CaO}, 4.42 \mathrm{Fe}_{2} \mathrm{O}_{3}, 3.76 \mathrm{MgO}, 1.62 \mathrm{~K}_{2} \mathrm{O}, 0.31 \mathrm{SO}_{3}, 0.55 \mathrm{TiO}_{2}, 0.04 \mathrm{MnO}, 0.18 \mathrm{P}_{2} \mathrm{O}_{5}, 0.017$ $\mathrm{Na}_{2} \mathrm{O}, 0.049 \mathrm{SrO}$ ) provides $Z=88 \%$ [99].

A more promising method for corrosion protection of metals is to use mixed CIs rather than individual ones [21, 31, 40]. Inhibitor formulations with halide anions [40], among which mixtures containing $\mathrm{I}^{-}$may be singled out, are most commonly used for the protection of metals in mineral acids. In some cases, addition of this anion to an organic CI substantially decreases steel corrosion even under extremely drastic conditions of hightemperature corrosion in $\mathrm{HCl}$ [100]. Strong inhibition of steel corrosion in $\mathrm{H}_{3} \mathrm{PO}_{4}$ solutions with $\mathrm{KI}$ as an individual additive can only be obtained at high $C_{\text {in }}$ values. In $2.5 \mathrm{M} \mathrm{H}_{3} \mathrm{PO}_{4}$ $\left(30-60^{\circ} \mathrm{C}\right.$ ) on carbon steel (content in mass percent, \%: $0.041 \mathrm{C}, 0.311 \mathrm{Mn}, 0.05 \mathrm{P}, 0.007$ $\mathrm{S}$, remainder $\mathrm{Fe}$ ), the presence of $50 \mathrm{mM} \mathrm{KI}$ provides $Z=97.1-99.6 \%$. The maximum $\mathrm{CI}$ inhibiting efficiency is found at $t$ near $50^{\circ} \mathrm{C}$. Reducing the CI content in solution to $20 \mathrm{mM}$ decreases $Z$ to $93.7-98.0 \%$ [101]. Formulations of $\mathrm{I}^{-}$with 6-benzylaminopurine [102], dodecylamine [103], bamboo leave extract and its components (rutin and orientin) [75], as well as the related additive benzyltrimethylammonium iodide [104] in $\mathrm{H}_{3} \mathrm{PO}_{4}$ solutions were studied. Formulations of $\mathrm{I}^{-}$with $\mathrm{N}$-containing compounds inhibit corrosion better than the individual mixture components. For example, for $1 \mathrm{mM}$ of 6-benzylaminopurine in $1 \mathrm{M} \mathrm{H}_{3} \mathrm{PO}_{4}\left(\right.$ at $20^{\circ}$ ) on cold rolled steel (content in mass percent, \%: $0.07 \mathrm{C}, 0.3 \mathrm{Mn}$, $0.022 \mathrm{P}, 0.010 \mathrm{~S}, 0.01 \mathrm{Si}, 0.030 \mathrm{Al}$, remainder $\mathrm{Fe}), Z=63.2 \%$, and for $1 \mathrm{mM} \mathrm{6-}$ benzylaminopurine $+1 \mathrm{mM} \mathrm{KI}, Z=95.3 \%$ [102]. Formulations of $\mathrm{I}^{-}$with dodecylamine [103], bamboo leave extract, rutin and orientin [75] demonstrate a synergistic effect of the components. Mixtures of $\mathrm{I}^{-}$with 6-benzylaminopurine [102], bamboo leave extract, rutin, orientin [75] and benzyltrimethylammonium iodide [104] lose their protective action with an increase in $t$. Formulations of (4-(2-pyridylazo)resorcin [105] and cetyltrimethylammonium bromide [106]) with chlorides have also been studied. They are substantially inferior to iodide formulations in protective action and are characterized by higher halide concentrations in solution. The degree of protection of formulations containing halide decreases in the series: $\mathrm{I}^{-}>\mathrm{Br}^{-}>\mathrm{Cl}^{-}$[107]. For example, in $3.5 \%$ of $\mathrm{H}_{3} \mathrm{PO}_{4}$ (at $30^{\circ} \mathrm{C}$ ) the degrees of steel protection (content in mass percent, \%: $0.012 \mathrm{C}, 0.005 \mathrm{P}, 0.017 \mathrm{~S}, 0.017$ $\mathrm{Si}, 0.07 \mathrm{Mn}$, remainder $\mathrm{Fe})$ by formulations of $11 \mu \mathrm{m}(E)-N^{\prime}-(1-(2$-hydroxyphenyl)ethylidene)-3-nitrobenzohydrazide and $0.01 \mathrm{M}$ potassium halides are $67.5 \%(\mathrm{KI}), 51.1 \%$ $(\mathrm{KBr})$ and $43.8 \%(\mathrm{KCl})$.

Formulations of sodium oleate with $\mathrm{Ce}(\mathrm{IV})$ [108] and red tetrazolium




$\mathrm{H}_{3} \mathrm{PO}_{4}\left(20-50^{\circ} \mathrm{C}\right)$ [109]. However, their protective action also decreases with an increase in $t$.

Protection synergism is observed when $\mathrm{Cu}$ (II) cations and $\mathrm{NO}_{3}^{-}$anions used as CIs are both present in corrosion medium for the protection of X18H10T chromium-nickel steel in hot $\mathrm{H}_{3} \mathrm{PO}_{4}$ solutions [110]. The specifics of the synergistic effect of these additives are addressed in [110, 111].

Stainless steel 904L (content in mass percent, \%: $0.013 \mathrm{C}, 1.84 \mathrm{Mn}, 0.145 \mathrm{Si}, 0.007 \mathrm{~S}$, $0.029 \mathrm{P}, 25.09 \mathrm{Ni}, 20.77 \mathrm{Cr}, 4.37 \mathrm{Mo}, 1.50 \mathrm{Cu}, 0.13 \mathrm{~W}$, remainder $\mathrm{Fe}$ ) in $40 \% \mathrm{H}_{3} \mathrm{PO}_{4}+4 \%$ $\mathrm{H}_{2} \mathrm{SO}_{4}+300 \mathrm{ppm} \mathrm{Cl}^{-}\left(80^{\circ} \mathrm{C}\right)$ is protected by adding 1,2,3-benzotriazole (BTA). In spite of the fact that in this system the $\mathrm{Cl}^{-}$anion acts as a synergistic additive to BTA, $Z=75 \%$ at the maximum concentration $C_{\mathrm{BTA}}=0.1 \mathrm{M}$ [112].

Along with two-component mixtures for protection the of steels in phosphoric acid media, patent literature recommends multicomponent formulations (Table 2), containing mandatory components such as urotropine (no less than one third of the inhibiting mixture weight) and azomethine (acetylacetone-o-aminophenol [113], acetylacetone-(6brompyrimidyl-5)-sulfanilamide [114], $\alpha$-naphthal- $\alpha$-naphthylamine [115], $\alpha$-hydroxynaphthalisonicotine hydrazide [116], $m$-nitro-benzal- $p$-iodoaniline [117], $p$-dimethylaminosalicylal-p-bromaniline [118], $p$-dipentylaminosalicylal-2-amino-4-nitrophenol [119], and 5-nitro-2-furfural- $\alpha$-naphthylamine [120]). As additives, these mixtures usually contain relatively hydrophobic components - S-containing organic compounds (dinitrophenylthiocyanate [113], 2,4,6-tris(2-isotioureido)-sim-triazine hydroiodide [116], 2-(thiazolyl-4)-BI [116], 3-ethyl-2[5'-(3'-ethylbenzthiazolinilidene-2' ')pentadiene-1,3'yl]benzothiazolium iodide [119], mercazolil [120]), fluoroorganic additives (4trifluoromethyl-2,6-dinitro-3-amino- $N, N$-diethylaniline [114], 4,5-dichloro-2-trifluoromethylbenzimidazole [117]) and iodide anions [116, 118, 119]. As accompanying components, some of the mixtures include N-containing molecular (dimethylamino-4hydroxy-5-butyl-6-methylpyrimidin [115], $N$-(heptylcarbamoyl)-imidazolidinone-2 [118], (indolyl-3)-acetic acid [119]), cationic (iodide methylethyloctyl-phenylammonium [118], 1,1'-dimethyl-4,4'-dipyryliumdi(o-methylsulfate) [120]) or anionic compounds (sodium dimethylaminoazobenzenesulphonate [114]). Regardless of the rather complex and diverse chemical compositions of these formulations, the majority of them [113, 114, 116-120] may, for simplification, be regarded as mixtures of $\mathrm{N}$-containing compounds of different origin with a relatively hydrophobic component, most often an S-containing compound $[112,116,119,120]$. In practical terms, the use of mixtures containing toxic organofluorine compounds $[114,117]$ seems unlikely. All the multicomponent CIs studied work in a wide range of media and may be used for inhibiting steel corrosion in $\mathrm{H}_{3} \mathrm{PO}_{4}$, $\mathrm{HCl}$ and $\mathrm{H}_{2} \mathrm{SO}_{4}$ solutions. 
Table $2 *$. Multicomponent inhibitors of metal acid corrosion designed for application in $\mathrm{H}_{3} \mathrm{PO}_{4}$ solutions.

\begin{tabular}{|c|c|c|c|c|}
\hline No. & Inhibitor chemical composition, mass \% & $\begin{array}{l}\text { Application } \\
\text { medium }\end{array}$ & Protected metal & Source \\
\hline 1 & $\begin{array}{c}\text { Acetylacetone-o-aminophenol }-18.2-29.7 \\
\text { 2,4-dinitrophenylthiocyanate }-22.7-24,3 \\
\text { urotropine }-45.9-59.1\end{array}$ & $\begin{array}{c}3 \mathrm{~N} \mathrm{H}_{3} \mathrm{PO}_{4} \\
\text { inhibitor }-3 \mathrm{~g} / 1\end{array}$ & $\begin{array}{l}\text { Steel, titanium, } \\
\text { zinc }\end{array}$ & 113 \\
\hline 2 & $\begin{array}{l}\text { 4-Trifluoromethyl-2,6-dinitro-3-amino- } N, N \text { - } \\
\text { diethylaniline } 9.4-11.4 ; \\
\text { acetylacetone-(6-bromopyrimidyl-5)- } \\
\text { sulfanilamide - } 14.1-17.1 ; \\
\text { sodium dimethylaminoazobenzenesulphonate } \\
\text { (Methyl Orange) }-20.0-34.3 ; \\
\text { urotropine - } 37.1-56.5 \text {. }\end{array}$ & $\begin{array}{c}5 \mathrm{~N} \mathrm{H}_{3} \mathrm{PO}_{4} \\
\text { inhibitor }-3 \mathrm{~g} / 1\end{array}$ & $\begin{array}{l}\text { Steel, titanium, } \\
\text { indium }\end{array}$ & 114 \\
\hline 3 & $\begin{array}{c}\alpha \text {-Naphthal- } \alpha \text {-naphthylamine }-17.5-29.0 \\
\text { dimethylamino-4-oxy-5-butyl-6- } \\
\text { methylpyrimidin }-22.9-30.1 \\
\text { urotropine }-59.6-40.9\end{array}$ & $\begin{array}{l}5 \mathrm{~N} \mathrm{H}_{3} \mathrm{PO}_{4} \\
\text { inhibitor }-5.8 \\
\quad \mathrm{~g} / \mathrm{l}\end{array}$ & $\begin{aligned} & \text { Steel, } \\
Z= & 94.1-99.6 \% . \\
& \text { Titanium, } \\
Z= & 45.0-69.2 \% . \\
& \text { Indium, } \\
Z= & 39.2-54.5 \% .\end{aligned}$ & 115 \\
\hline 4 & $\begin{array}{l}\alpha \text {-Oxynaphthalisonicotine hydrazide - } \\
\text { 11.1-14.7; } \\
\text { 2,4,6-tris(2-Isotioureido)-sym-triazine } \\
\text { hydroiodide }-15.0-10.3 \text {; } \\
\text { 2-(Thiazolyl -4)-benzimidazole - 33.4- } \\
\text { 25.0; } \\
\text { urotropine }-40.5-50.0\end{array}$ & $\begin{array}{l}5 \mathrm{~N} \mathrm{H}_{3} \mathrm{PO}_{4} \\
\text { inhibitor }-5 \mathrm{~g} / 1\end{array}$ & $\begin{array}{c}\text { Steel, } \\
Z=94.3-99.7 \% . \\
\text { Aluminum, } \\
Z=71.7-78.7 \% . \\
\text { Indium, } \\
Z=45.0-55.8 \% .\end{array}$ & 116 \\
\hline 5 & $\begin{array}{l}m \text {-Nitro-benzal- } p \text {-iodoaniline }-14.8-17.9 \\
\quad 4,5 \text {-dichloro-2- } \\
\text { trifluoromethylbenzimidazole }-33.3-23.9 \\
\text { Urotropine }-51.9-58.2\end{array}$ & $\begin{array}{l}5 \mathrm{~N} \mathrm{H}_{3} \mathrm{PO}_{4} \\
\text { inhibitor }-4.8 \\
\quad \mathrm{~g} / \mathrm{l}\end{array}$ & $\begin{array}{c}\text { Steel, } \\
Z=94.1-99.4 \% . \\
\text { Aluminum, } \\
Z=87.0-91.6 \% . \\
\text { Indium, } \\
Z=48.5-58.9 \% .\end{array}$ & 117 \\
\hline 6 & $\begin{array}{c}p \text {-Dimethylaminosalicylal- } p \text {-bromoaniline - } \\
18.1-23.9 ; \\
N \text {-(Heptylcarbamoyl)imidazolidinone-2 - } \\
11.9-13.7 ; \\
\text { Methylethyloctylphenylammonium iodide - } \\
16.4-27.3 ; \\
\text { Urotropine }-40.9-47.8 .\end{array}$ & $\begin{array}{l}3 \mathrm{~N} \mathrm{H}_{3} \mathrm{PO}_{4} \\
\text { inhibitor }-3.2 \\
\quad \mathrm{~g} / \mathrm{l}\end{array}$ & $\begin{array}{c}\text { Steel, } \\
Z=95.8-99.5 \% . \\
\text { Zinc, } \\
Z=88.1-97.0 \% . \\
\text { Tin, } \\
Z=70.1-73.9 \% .\end{array}$ & 118 \\
\hline 7 & $\begin{array}{l}\text { Dipentylaminosalicylal-2-amino-4- } \\
\text { nitrophenol - } 15.8-12,1\end{array}$ & $\begin{array}{l}5 \mathrm{~N} \mathrm{H}_{3} \mathrm{PO}_{4} \\
\text { inhibitor }-3,2 \\
\quad \mathrm{~g} / 1\end{array}$ & $\begin{array}{c}\text { Steel, } \\
Z=94.5-99.7 \% .\end{array}$ & 119 \\
\hline
\end{tabular}




\section{No. Inhibitor chemical composition, mass \% Application $\quad$ Protected metal Source medium}

\begin{tabular}{|c|c|c|c|c|}
\hline & $\begin{array}{c}\text { (Indolyl-3)acetic acid }-10.3-15.0 ; \\
\text { 3-Ethyl-2 [5'-(3'-ethylbenzthiazolinilidene- } \\
\text { 2')pentadiene-1,3'-yl]benzothiazolium }^{\prime \prime} \text { iodide }-25.9-32.3 \\
\text { Urotropine }-48.0-40.6 \text {. }\end{array}$ & & $\begin{aligned} & \text { Titanium }, \\
Z= & 80.1-93.0 \% . \\
& \text { Indium }, \\
Z= & 46.9-58.0 \% .\end{aligned}$ & \\
\hline 8 & $\begin{array}{c}\text { 5-Nitro-2-furfural- } \alpha \text {-naphthylamine - } \\
\text { 8.7-10.5; } \\
\text { di(o-Methylsulfate)-1,1'- dimethyl-4,4' - } \\
\text { dipyrylium - } 12.9-23.0 \\
\text { Mercazolilum - 29.1-33.6; } \\
\text { Urotropine }-49.3-32.9 .\end{array}$ & $\begin{array}{c}0,03 \div 5 \mathrm{~N} \\
\mathrm{H}_{3} \mathrm{PO}_{4}, \\
\text { inhibitor }-2,5 \\
\mathrm{~g} / \mathrm{l}\end{array}$ & $\begin{aligned} & \text { Steel, } \\
Z= & 94.5-99.7 \% . \\
& \text { Titanium, } \\
Z= & 48.1-57.0 \% . \\
& \text { Aluminum, } \\
Z= & 63.3-79.2 \% .\end{aligned}$ & 120 \\
\hline
\end{tabular}

$*$ results of measurements performed at $20^{\circ} \mathrm{C}$ and $90^{\circ} \mathrm{C}$.

Article [121] describes a failed attempt of mild steel protection in $40 \% \mathrm{H}_{3} \mathrm{PO}_{4}\left(40^{\circ} \mathrm{C}\right)$ with composite CIs containing $10 \mathrm{mM}$ of an S-containing amino acid (methionine, cystine, cysteine, $N$-acetylcysteine), $\mathrm{Cl}^{-}$and $\mathrm{F}^{-}$, Fe(III). Such formulations provide $Z_{\max }=78 \%$, while for a binary amino acid mixture with $\mathrm{Cl}^{-}, Z_{\max }=87 \%$.

Binary $\mathrm{CIs}$ including $\mathrm{N}$-containing organic compounds and S-containing ones capable of protection even in hot acid solutions are interesting for $\mathrm{H}_{3} \mathrm{PO}_{4}$ solutions. In $2 \mathrm{M} \mathrm{H}_{3} \mathrm{PO}_{4}$ $\left(60^{\circ}\right)$, adding $5 \mathrm{mM}$ of citralidenebenzylamine $+5 \mathrm{mM}$ KNCS decreases the corrosion rate $k$ of St3 steel 96-fold, while addition of $5 \mathrm{mM}$ sodium diethyldithiocarbamate (DDTC) decreases the $k$ value 84-fold [58]. Under the same conditions, the mixture of $5 \mathrm{mM}$ of $N$ (2-chlorophenyl)-1,3,5-triazine-2,4-diamine derivatives with the formula:

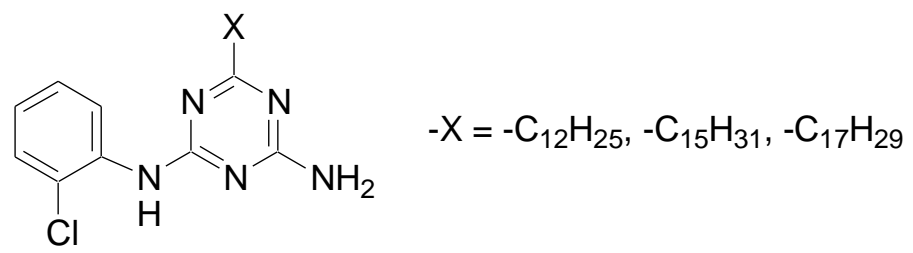

with $0.5 \mathrm{mM}$ KNCS inhibits corrosion 29-41 fold [122]. On steel 10 in $4 \mathrm{~N} \mathrm{H}_{3} \mathrm{PO}_{4}\left(\right.$ at $\left.80^{\circ}\right)$ for a series of formulations of waste from industrial production of morpholine with captax or thiocarbamide ( $3 \mathrm{~g} / \mathrm{l}), Z=97.7-99.2 \%$ according to 1 -hour tests [123].

In practical terms, the use of mixtures of triazole derivatives with $\mathrm{S}$-containing compounds seems promising. Such formulations based on 3-substituted 1,2,4-triazole, the IFKhAN-92 CI, efficiently inhibit low carbon steel corrosion [11, 124, 125], although individual components of these mixtures do it poorly (Figure 1). Mixtures of this triazole with anionic sulphur-containing additives (KNCS, DDTC, $\mathrm{Na}_{2} \mathrm{~S}$ ) give the maximum reduction of corrosion: they provide at least 10 times smaller $k$ values than KI-containing formulations. 


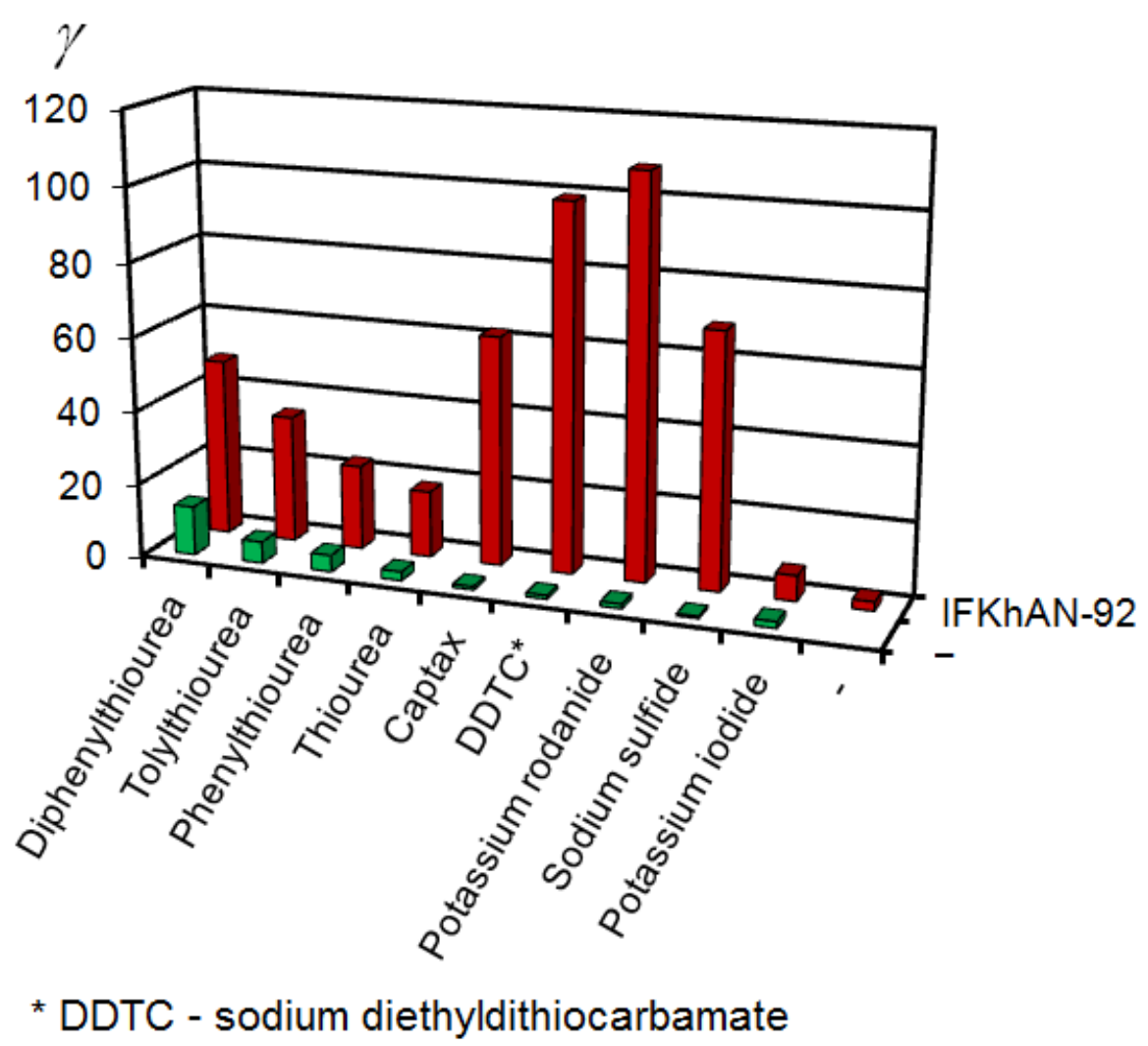

Figure 1. Steel corrosion inhibition factors for St3 steel in $2 \mathrm{M} \mathrm{H}_{3} \mathrm{PO}_{4}\left(t=60^{\circ} \mathrm{C}\right)$ by sulphurcontaining compounds $(0.5 \mathrm{mM})$ and their mixtures with $5.0 \mathrm{mM}$ IFKhAN-92. Test duration $2 \mathrm{~h}$.

Using mixtures of a 3-substituted 1,2,4-triazole with KNCS and captax as an example (Figure 2), the possibility of protecting low carbon steel in $\mathrm{H}_{3} \mathrm{PO}_{4}$ solutions within a wide range of concentrations $(2.0-8.0 \mathrm{M})$ and temperatures $\left(0-95^{\circ} \mathrm{C}\right)$ was shown $[11,124$, 125]. A systematic growth in $\gamma_{\text {mix }}$ with an increase in $t$ is observed. The temperature maximum of the mixtures' efficiency is not reached at least up to $95^{\circ} \mathrm{C}$, which allows one to consider them as "high-temperature CIs" [29]. In solutions with these additives the average $k$ of St3 steel goes down with increasing duration of corrosion testing. In case of the $5 \mathrm{mM}$ triazole $+0.5 \mathrm{mM}$ KNCS mixture, the resulting $\gamma=233$ in a $6 \mathrm{~h}$ test, or 59 in a $0.5 \mathrm{~h}$ test.

The resistance of CIs for acid corrosion of steels to the impact of iron cations is an important process parameter allowing their use under real industrial conditions where the etching solutions necessarily contain iron salts, but in such media the vast majority of compounds inhibiting corrosion of steels lose the capacity to protect the metal. The formulation of triazole with KNCS maintains a high protective action in $\mathrm{H}_{3} \mathrm{PO}_{4}$ solution containing $\mathrm{Fe}^{2+}$ as well as $\mathrm{Fe}^{3+}$ ions (Figure 3) due to inhibition of their cathodic reduction occurring in diffusion mode, which is unique among CIs [126]. 




Figure 2. Steel corrosion inhibition factors for $\mathrm{St} 3$ steel in $\mathrm{H}_{3} \mathrm{PO}_{4}$ solutions by combinations of IFKhAN-92 with KNCS and captax at various temperatures $(a)$ and acid concentrations $(b)$. Test duration $-2 \mathrm{~h}$.

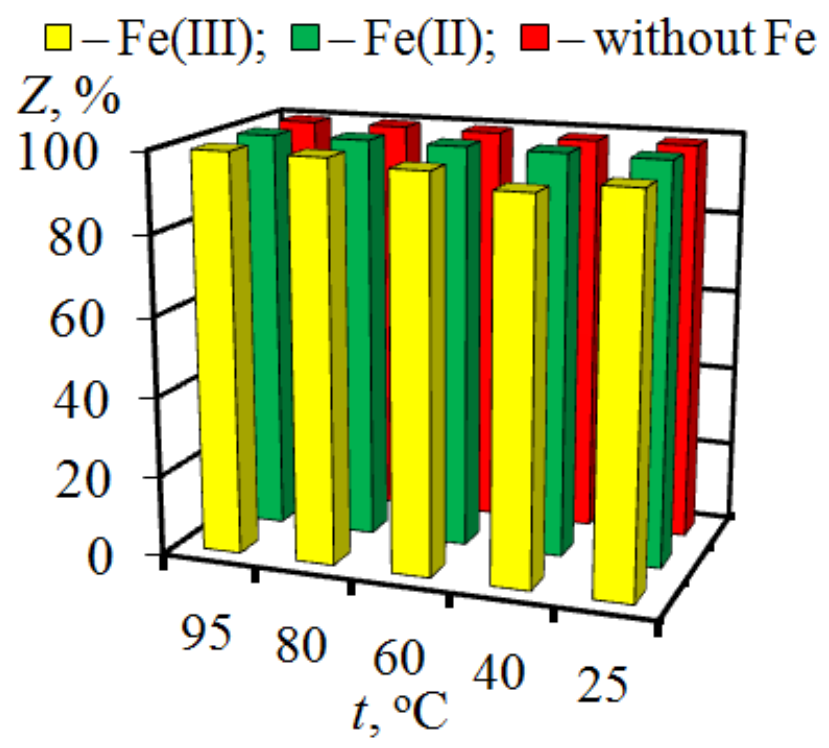

Figure 3. Influence of $\mathrm{Fe}(\mathrm{III})$ and $\mathrm{Fe}(\mathrm{II})$ cations $(C=0.10 \mathrm{M})$ on corrosion inhibition of St3 steel in $2 \mathrm{M} \mathrm{H}_{3} \mathrm{PO}_{4}$ by combination of $5.0 \mathrm{mM}$ IFKhAN-92 and $0.5 \mathrm{mM} \mathrm{KNCS}$. Test duration $-2 \mathrm{~h}$.

Examples of protection of nonferrous metals by organic CIs in $\mathrm{H}_{3} \mathrm{PO}_{4}$ solutions are also known. For example, for pure aluminum in $1 \mathrm{M} \mathrm{H}_{3} \mathrm{PO}_{4}$ the mixture of $10 \mathrm{mM}$ purine with $0.1 \mathrm{mM} \mathrm{KI}\left(25^{\circ}\right)$ provides $Z=92 \%$ [127]. Formulations of unsaturated ketones (benzalacetophenone, dibenzalacetone, dibenzal-1,4-diacetylbenzene) with halide anions [128] are less efficient in this respect. The protective action of such mixtures on aluminum (content in mass percent, \%: $0.483 \mathrm{Si}, 0.180 \mathrm{Fe}, 0.001 \mathrm{Cu}, 0.405 \mathrm{Mg}, 0.017 \mathrm{Zn}, 0.015 \mathrm{Ti}$, $0.004 \mathrm{Cr}, 0.005 \mathrm{Ni}$, remainder $\mathrm{Al})$ in $1 \mathrm{M} \mathrm{H}_{3} \mathrm{PO}_{4}\left(30^{\circ}\right)$ decreases in the series: $\mathrm{I}^{-}>\mathrm{Br}^{-}>$ 
$\mathrm{Cl}^{-}$. For the most efficient formulation, $11 \mu \mathrm{m}$ dibenzal-1,4-diacetylbenzene $+10 \mathrm{mM} \mathrm{KI}$, $Z=80 \%$. For a similar mixture containing $\mathrm{KBr}, Z=76 \%$, and $Z=70 \%$ for the mixture containing $\mathrm{KCl}$. An aqueous extract of coriander (Coriandrum sativum L.) seed was offered as an "environment-friendly" CI for aluminum (content in mass percent, \%: 0.120 $\mathrm{Si}, 0.270 \mathrm{Fe}$, remainder $\mathrm{Al}$ ) and 6063 alloy (content in mass percent, \%: $0.41 \mathrm{Si}, 0.11 \mathrm{Fe}$, $0.05 \mathrm{Cu}, 0.49 \mathrm{Mg}$, remainder $\mathrm{Al})[129,130]$. According to the results of voltammetry and electrochemical impedance spectroscopy (EIS), the extract of coriander seeds (up to $0.05 \%)$ in $\mathrm{H}_{3} \mathrm{PO}_{4}\left(30-50^{\circ} \mathrm{C}\right)$ provides $Z \leq 75 \%$. A similar effect $(Z \leq 79 \%)$ for aluminum protection, according to voltammetry and EIS data, is provided by adding $10 \mathrm{mg} / \mathrm{l}$ of essential oil from Mentha Pulegium leaves to $2 \mathrm{M} \mathrm{H}_{3} \mathrm{PO}_{4}\left(25^{\circ} \mathrm{C}\right)$ [131]. A less efficient extract from leaves of Dendrocalamus brandisii [132] on aluminum (content in mass percent, \%: $0.25 \mathrm{Si}, 0.35 \mathrm{Fe}, 0.05 \mathrm{Cu}, 0.03 \mathrm{Mg}, 0.05 \mathrm{Zn}, 0.03 \mathrm{Ti}, 0.05 \mathrm{~V}$, remainder $\mathrm{Al}$ ) in $0.5-3 \mathrm{M} \mathrm{H}_{3} \mathrm{PO}_{4}\left(20-50^{\circ} \mathrm{C}\right)$ gives $Z<50 \%$. The protective action of this extract decreases with increasing $t$ and increasing $C_{\mathrm{H} 3 \mathrm{PO} 4}$. In very dilute solutions $\left(0.033-0.167 \mathrm{M} \mathrm{H}_{3} \mathrm{PO}_{4}\right.$, $30^{\circ} \mathrm{C}$ ), the corrosion of B26S copper-aluminum alloy (content in mass percent, $\%: 3.88 \mathrm{Cu}$, $0.87 \mathrm{Mn}$, up to $0.59 \mathrm{Si}$, up to $0.71 \mathrm{Fe}$, up to $0.32 \mathrm{Mg}$, remainder $\mathrm{Al}$ ) is inhibited by aniline derivatives (up to $0.5 \mathrm{~g} / \mathrm{l}$ ), of which $p$-toluidine provides the best protective effect, in some cases almost totally suppressing corrosion [133]. The impact of aniline derivatives on aluminum corrosion in this medium is based on its ability of partially neutralizing highly dilute solutions of the acid.

For inhibition of aluminum corrosion, patent literature (Table 2) recommends several aforementioned multicomponent inhibitor formulations, which include urotropine and azomethine with addition of an S-containing compound [116, 120] or a fluoroorganic compound [117].

Inorganic compounds are used for the protection of aluminum alloys in phosphoric acid media along with organic CIs. For example, adding $\mathrm{Na}_{2} \mathrm{MoO}_{4}(C \leq 20 \mathrm{mM})$ to $1 \mathrm{M}$ $\mathrm{H}_{3} \mathrm{PO}_{4}\left(25^{\circ}\right.$ ) allows inhibiting the corrosion of an aluminum alloy (content in mass percent, \%: $0.25 \mathrm{Si}, 0.35 \mathrm{Fe}, 0.05 \mathrm{Cu}, 0.03 \mathrm{Mn}, 0.03 \mathrm{Mg}, 0.05 \mathrm{Zn}, 0.03 \mathrm{Ti}, 0.05 \mathrm{~V}$, remainder $\mathrm{Al}$ ) with $Z \leq 90 \%$ [134]. The corrosion of A383 aluminum-silicon alloy (content in mass percent, \%: 10.6 Si, 0.918 Fe, 2.52 Cu, 0.21 Mn, 0.057 Mg, 0.052 Sn, 2.91 Zn, 0.05 Ni, $0.069 \mathrm{Cr}, 0.052 \mathrm{~Pb}, 0.041 \mathrm{Na}, 0.038 \mathrm{Ti}$, remainder $\mathrm{Al})$ in $0.5 \mathrm{M} \mathrm{H}_{3} \mathrm{PO}_{4}$ can be inhibited $(Z$ $=95 \%$ ) by using the $0.1 \mathrm{M} \mathrm{K}_{2} \mathrm{CrO}_{4}$ additive $[135,136]$.

For zinc protection in dilute $\mathrm{H}_{3} \mathrm{PO}_{4}$ solutions $(0.01-0.15 \mathrm{M})$ at ambient $t$, aniline [137], urotropine [138] and 4-aminoantipyrine [139] are used. In $1 \mathrm{M} \mathrm{H}_{3} \mathrm{PO}_{4}\left(25^{\circ}\right)$, zinc corrosion is inhibited by adding $0.5-7.0 \mathrm{mM}$ 2-thiophenecarboxaldehyde (TPhCA) with $Z=53$ $96 \%$ [140]. Increasing $t$ to $65^{\circ} \mathrm{C}$ weakens metal protection by the inhibitor, and at $1 \mathrm{mM}$ TPhCA, the $Z$ value decreases from 65 to $35 \%$. Better inhibition of the corrosion of zinc (spectroscopically pure, 99.9\%)) in $1 \mathrm{M} \mathrm{H}_{3} \mathrm{PO}_{4}\left(25^{\circ}\right)$ is provided by $2 \mathrm{mM}$ 2-mercapto-BI, $Z=98 \%$ [141]. The use of a mixture of acetylacetone- $o$-aminophenol, dinitrophenylthiocyanate and urotropine $(3 \mathrm{~g} / \mathrm{l})$ decreases the zinc corrosion rate in $1 \mathrm{M} \mathrm{H}_{3} \mathrm{PO}_{4}\left(20^{\circ} \mathrm{C}\right)$ 
only 13-fold [113]. More promising for the protection of this metal is the use of substituted triazole IFKhAN-92, which, at a concentration of $5 \mathrm{mM}$ in $2 \mathrm{M} \mathrm{H}_{3} \mathrm{PO}_{4}\left(25-60^{\circ} \mathrm{C}\right)$, slows down the corrosion of Ts1 zinc 15-26 fold [142]. In $1 \mathrm{M} \mathrm{H}_{3} \mathrm{PO}_{4}\left(20-90^{\circ} \mathrm{C}\right), 3.2 \mathrm{~g} / \mathrm{l}$ of a four-component mixture ( $p$-dimethylaminosalicylal-p-bromoaniline $+N$-(heptylcarbamoyl)-imidazolidinone- $2+$ methylethyloctylphenylammonium iodide + urotropine) [118] provides $Z=88.1-97.0 \%$ on zinc.

In the protection of copper alloys in phosphoric acid solutions, 3-mercapto-1,2,4triazole, benzotriazole, thiophene, tetrahydrothiophene [143], 1-butyl-4-methylpyridinium tetrafluoroborate [144], oil of Artemisia Astéracées plant [145] and extract of sea algae Sargassum wightii [146] demonstrate weak inhibiting properties. Multicomponent mixtures (Table 2) containing urotropine, azomethine and an additive of hydrophobic origin are capable of preventing corrosion of titanium [113-115, 119, 120], indium [114$117,119]$ and $\operatorname{tin}[118]$ in $1 \mathrm{M} \mathrm{H}_{3} \mathrm{PO}_{4}$.

Let us separately consider the CIs introduced into acidic phosphate formulations to remove products of atmospheric corrosion (rust converters, RC) from the surface of steels. For example, adding $0.5-1 \%$ catapin KI-1 prevents the undesirable dissolution of the surface of 20X13 and 40X13 stainless steels with low chromium content when treated with $\mathrm{RC}$ with the following composition, g/ $\mathrm{kg}: \mathrm{H}_{3} \mathrm{PO}_{4} 200-300$, oxalic acid 5-10, surfactant 16 , silicon dioxide $40-75$, water up to $1 \mathrm{~kg}$ [147]. Triethanolamine $(0.2-0.3 \%)$ is added to decrease the corrosivity of a frost-resistant $\mathrm{RC}$ (content in mass percent, \%: $\mathrm{H}_{3} \mathrm{PO}_{4} 3.0-$ 5.0, alcohol $\mathrm{C}_{1}-\mathrm{C}_{4}$ or their mixtures 79.5-86.0, water 11.0-15.0) [148].

In some cases, $\mathrm{H}_{3} \mathrm{PO}_{4}$ added to an $\mathrm{HCl}$ solution can itself play the role of a corrosion inhibitor. For example, adding $1 \% \mathrm{H}_{3} \mathrm{PO}_{4}$ to $1 \mathrm{M} \mathrm{HCl}$ (at ambient $t$ ) allows the corrosion rate of X18H10T steel to be reduced 70-fold [149]. However, this effect is unstable and depends on the composition of the solutions and the corrosion duration. The corrosion of low-carbon steel (content in mass percent, \%: $0.16 \mathrm{C}, 0.16 \mathrm{Si}, 0.53 \mathrm{Mg}$, remainder $\mathrm{Fe}$ ) in $1 \mathrm{M} \mathrm{HCl}\left(30^{\circ} \mathrm{C}\right)$ is decreased by adding $0.015 \%$ of a combination of tannin and $\mathrm{H}_{3} \mathrm{PO}_{4}$ (1:1) with $Z=61 \%$, against 72 and $55 \%$ for tannin and $\mathrm{H}_{3} \mathrm{PO}_{4}$ themselves. The presence of $\mathrm{H}_{3} \mathrm{PO}_{4}$ in etching solution gives steel samples resistance to corrosion in the atmosphere and prevents corrosion damage from appearing on their surface for 3 weeks, against on the $1^{\text {st }}$ week for samples kept in the acid inhibited solely by tannin [150].

Analysis of literature shows that at present no CIs of metals for $\mathrm{H}_{3} \mathrm{PO}_{4}$ solutions are commercially produced in the RF. Except for S-containing compounds, individual organic CI weakly inhibit steel corrosion in $\mathrm{H}_{3} \mathrm{PO}_{4}$ solutions. S-containing compounds substantially lose protective properties upon rising $t$ even to $50^{\circ} \mathrm{C}$. Mixed CIs consisting of $\mathrm{N}$-containing compounds and relatively hydrophobic S-containing compounds have a better protective action in $\mathrm{H}_{3} \mathrm{PO}_{4}$. More promising are mixtures of triazole derivatives and $\mathrm{S}$-containing compounds that can substantially reduce the $k$ of metals even in hot acid solutions ( $t$ up to $100^{\circ} \mathrm{C}$ ), and in the case of steels are capable of maintaining protective action in the 
presence of $\mathrm{Fe}(\mathrm{II})$ and $\mathrm{Fe}(\mathrm{III})$ cations. It is very important for CIs used in acid etching of steels.

Attention should be paid to the group of metal CIs for $\mathrm{H}_{3} \mathrm{PO}_{4}$ claimed to be "environment-friendly". They are often produced by extraction from various parts of plants. They all show poor results in metal protection, and their effect cannot be substantially improved even by combining them with such a well-known synergist as the iodide anion.

\section{The specifics of the mechanism of inhibitor action in mixtures of triazoles and sulphur-containing compounds on steels in phosphoric acid solutions}

As a rule, the reasons for the low efficiency of organic CIs toward steels in $\mathrm{H}_{3} \mathrm{PO}_{4}$ solutions are not discussed. It is probably caused by build-up of insoluble surface phosphates on a metal that prevent the adsorption of CIs. As a result, compounds capable of only physical interaction with the steel surface are poorly adsorbed on the metal surface and weakly protect steel. This is proved by the fact that many of these CIs (acetylene derivatives [57], azomethines [58], quaternary ammonium compounds (QAC) [59], Ncontaining heterocycles $[11,31,59,124,125])$ show higher protective effects in other mineral acids and, in particular, in $\mathrm{HCl}$. In addition, propargyl alcohol [151], some QAC and triazoles $[11,59,124,125]$ improve efficiency on transition to concentrated $\mathrm{H}_{3} \mathrm{PO}_{4}$ solutions where soluble acid iron phosphates emerge, thus freeing the metal surface. It is logical to assume that high protection of steels can only be obtained here by CIs chemically interacting with steel and competing in adsorption with iron phosphates. The situation may be made clear by analyzing the regularity in the adsorption of organic CIs on steels in $\mathrm{H}_{3} \mathrm{PO}_{4}$.

The adsorption of individual organic compounds (N-1-naphthylethylenediamine dihydrochloride [60], barbiturates [69], 2-isopropyl-5-methylphenol [70], rutin, orientin [75], 6-benzylaminopurine [102], benzyltrimethylammonium iodide [104]) on steel in $\mathrm{H}_{3} \mathrm{PO}_{4}$ solutions is described by the Langmuir isotherm, that of $\mathrm{BI}$ derivative is described by the Flory-Huggins isotherm [61], that of benzyltriphenylphosphonium chloride [63], quaternary salts of pyridinium and quinolinium [64] is described by the El Avadi isotherm, and that of sodium oleate is described by the Temkin isotherm [108]. The free energy of their adsorption $\left(-\Delta G_{\mathrm{ads}}\right)$ on steels is substantially lower than $40 \mathrm{~kJ} / \mathrm{mol}$ that could allow chemisorbtion of a CI on steel to be assumed. This result well agrees with the low efficiency of these compounds in corrosion inhibition of steel in $\mathrm{H}_{3} \mathrm{PO}_{4}$. Adsorption of $\mathrm{I}^{-}$ (inorganic additive) also complies with the Langmuir isotherm with $\left(-\Delta G_{\text {ads }}\right)=29.6 \mathrm{~kJ} / \mathrm{mol}$ [101]. Addition of this ion to rutin, orientin, 6-benzylaminopurine, as well as addition of $\mathrm{Ce}(\mathrm{IV})$ ions to sodium oleate increases the adsorption energy of organic compounds, although the value of $\left(-\Delta G_{\text {ads }}\right)=40 \mathrm{~kJ} / \mathrm{mol}$ is not reached. Only in the absorption of 1 dodecyl-5-methyl-1H-benzo[d][1,2,3]triazol-1-ium bromide on carbon steel described by 
the Langmuir isotherm, a high value of $\left(-\Delta G_{\text {ads }}\right)=37-42 \mathrm{~kJ} / \mathrm{mol}$ [65] is observed, which allows chemical interaction of this BTA derivative with steel surface to be assumed.

Stronger interaction of steel surface and inhibitor is observed for S-containing compounds, such as allylthiourea $\left(\left(-\Delta G_{\text {ads }}\right)=37.6-40.4 \mathrm{~kJ} / \mathrm{mol}\right) \quad[78], 4-(N, N-$ diethylamino)benzaldehydethiosemicarbazone (32-34 kJ/mol) [81], thiosemicarbazide and its derivatives $(38-40 \mathrm{~kJ} / \mathrm{mol})$ [79], 1,2-bis(thiophen-2-ylidenemethyl)hydrazine (38 kJ/mol) [91], 3,4-dimethoxybenzaldehydethiosemicarbazone $(40-43 \mathrm{~kJ} / \mathrm{mol})$ [82], benzothiazole derivatives $(44.5-52.2 \mathrm{~kJ} / \mathrm{mol})$ [86], 4-amino-3-hydrazino-5-mercapto-1,2,4triazole $(38.3 \mathrm{~kJ} / \mathrm{mol})$ [87], 3-phenyl-4-amino-5-mercapto-1,2,4-triazole $(36.1 \mathrm{~kJ} / \mathrm{mol})$ [88], a thiophene derivative $(38.3 \mathrm{~kJ} / \mathrm{mol})$ [89], that also inhibit steel corrosion better. The adsorption of these compounds obeys the Langmuir isotherm. Judging from the high adsorption energy $\left(-\Delta G_{\mathrm{ads}}\right) \geq 40 \mathrm{~kJ} / \mathrm{mol}$, we can assume with high probability that BTA derivatives, 3,4-dimethoxybenzaldehydethiosemicarbazone, some thiosemicarbazide derivatives and allylthiourea are chemisorbed on steel surface.

Data on the adsorption of organic CIs on nonferrous metals in $\mathrm{H}_{3} \mathrm{PO}_{4}$ are fragmentary, but they exclusively support the absence of chemisorption interaction of these metals with the compounds in question. Low $\left(-\Delta G_{\text {ads }}\right)$ values of organic CIs on aluminum are observed in $\mathrm{H}_{3} \mathrm{PO}_{4}$ solutions where they are not efficient. $\left(-\Delta G_{\mathrm{ads}}\right)=17.3 \mathrm{~kJ} / \mathrm{mol}$ for the mixture of compounds produced from the Dendrocalamus brandisii plant [132], and even lower (4.7$5.8 \mathrm{~kJ} / \mathrm{mol}$ ) for unsaturated ketones [128]. Better adsorption is observed for TPhCA on zinc with $\left(-\Delta G_{\text {ads }}\right)=28.9 \mathrm{~kJ} / \mathrm{mol}$ [140] and for 1-butyl-4-methylpyridinium tetrafluoroborate on copper (23.3-24.7 kJ/mol) [144]. In all the cases, adsorption is described by the Langmuir isotherm.

Mixtures of triazoles with $\mathrm{S}$-containing additives have high protective effects on steel corrosion in $\mathrm{H}_{3} \mathrm{PO}_{4}$, including hot solutions ( $t$ up to $100^{\circ} \mathrm{C}$ ). It is logical to expect that the components of these mixtures interact with the metal surface in a chemisorption manner, thus ensuring substantial corrosion inhibition. In fact, it has been shown that adsorption of a 3-substituted 1,2,4-triazole on cathodically polarized low-carbon steel from acid solutions is described by the Temkin isotherm (Figure 4) with a relatively high free adsorption energy $\left(-\Delta G_{\text {ads }}\right)=51 \pm 1 \mathrm{~kJ} / \mathrm{mol}$, indicating the chemical nature of binding inhibitor molecules with the metal surface atoms [152]. Its adsorption kinetics is described by the Roginsky-Zeldovich equation (Figure 5), which is also in favor of CI chemisorption. Addition of KNCS to an $\mathrm{H}_{3} \mathrm{PO}_{4}$ solution speeds up the adsorption of the triazole on steel, which is evidenced by an increase in the rate constant in this equation in the presence of this compound. This explains the higher efficiency of the mixed CI in steel corrosion inhibition in $\mathrm{H}_{3} \mathrm{PO}_{4}$ in comparison with the triazole itself. Probably, the $\mathrm{NCS}^{-}$ anions that are adsorbed on the metal decrease the positive charge on the steel surface. As a result, the adsorption of the triazole present in the form of an organic cation accelerates. Ultimately, this allows a higher protection effect to be obtained than by the triazole itself, 
even under mode drastic conditions in the absence of cathodic protection at the free corrosion potential, $E_{\text {cor }}[152]$.

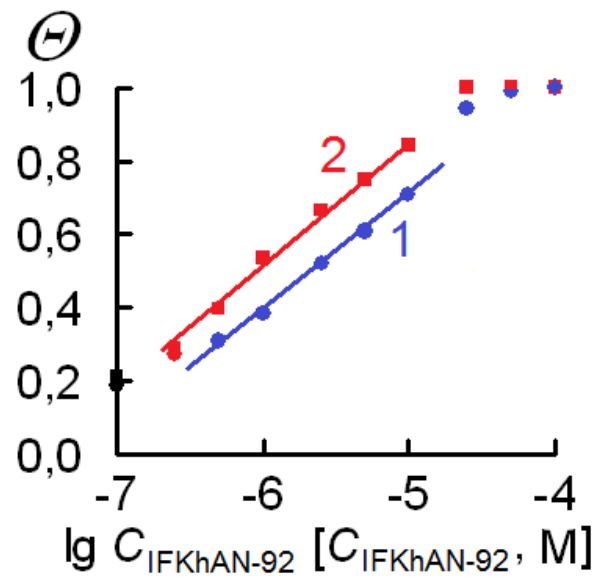

Figure 4. Adsorption isotherm of IFKhAN-92 (1) and its mixture with $0.5 \mathrm{mM} \mathrm{KNCS} \mathrm{(2)} \mathrm{on}$ St3 steel $(E=-0.30 \mathrm{~V})$ from $2 \mathrm{M} \mathrm{H}_{3} \mathrm{PO}_{4}\left(22^{\circ} \mathrm{C}\right)$. Points - measured values, straight line theoretical dependence for the Temkin isotherm.



Figure 5. Dependence of the coverage of St3 steel surface with inhibitor $(E=-0.30 \mathrm{~V})$ on the logarithm of its adsorption time in $2 \mathrm{M} \mathrm{H}_{3} \mathrm{PO}_{4}\left(22^{\circ} \mathrm{C}\right)$ containing IFKhAN-92 (a) and its combination with $0.5 \mathrm{mM} \mathrm{KNCS}(b)$, with concentrations in $\mu \mathrm{m}: 1-2.5,2-5.0,3-10$. Points - observed dependences. Straight lines - theoretical dependence for the RoginskyZeldovich equation.

It has been shown by X-ray photoelectron spectroscopy that upon adsorption from $\mathrm{H}_{3} \mathrm{PO}_{4}$ solutions on the steel surface at $E_{\text {cor }}$, formulations of the 3-substituted 1,2,4-triazole and KNCS form a polymolecular protective layer more than $4 \mathrm{~nm}$ thick, presumably consisting of a complex combination of triazole molecules, Fe(II) cations and $\mathrm{NCS}^{-}$that has a polymeric nature. This layer is chemically bound to the steel surface, which determines its ability to remain on the metal even during its ultrasonic cleaning. In background acid solutions such CI layers provide high protection of steel (Figure 6) [153]. 




Figure 6. Protective after-effect of inhibitor layers formed on the surface of St3 steel in $2 \mathrm{M}$ $\mathrm{H}_{3} \mathrm{PO}_{4}+5 \mathrm{mM}$ IFKhAN-92 + $5 \mathrm{mM} \mathrm{KNCS}\left(20^{\circ} \mathrm{C}\right)$ in $2 \mathrm{M} \mathrm{H}_{3} \mathrm{PO}_{4}$ solution $(2 \mathrm{~h})$. 1 - samples after preliminary inhibitor adsorption $(24 \mathrm{~h}), 2$ - samples after preliminary inhibitor adsorption (24 h) followed by ultrasonic washing, 3 - samples without preliminary inhibitor adsorption.

The protective CI layers formed by the formulation of the triazole and KNCS on the steel surface strongly inhibit the electrode reactions of steel in $\mathrm{H}_{3} \mathrm{PO}_{4}$ solution at $t \leq 95^{\circ} \mathrm{C}$, thus enabling efficient protection of steel under these conditions [154].

Therefore, the high efficiency of mixtures of triazoles and KNCS in the corrosion of steel in $\mathrm{H}_{3} \mathrm{PO}_{4}$ solutions results from the capability of such heterocycles to be chemisorbed on steel and form on its surface, jointly with $\mathrm{Fe}(\mathrm{II})$ and $\mathrm{NCS}^{-}$, protective layers similar in structure to polymeric complexes. This mechanism of protective action of the mixed CI is largely determined by the unique structure of the triazole is one of the mixture components and that exhibits the properties of a bidentate ligand. As a result, the CI is not only chemisorbed but also forms a polymeric protective layer on steel [153].

In addition, rhodanide anions speed up the adsorption of triazoles on steel, thus contributing to the inhibitive effect of the mixture. It is important to note that often in studying the protection mechanism of CIs is acids, the role of kinetics of their adsorption on metals is not taken into account, although, as shown in [152], this factor can play the predominant role in metal protection.

\section{Inhibited acid solutions based on $\mathrm{H}_{3} \mathrm{PO}_{4}$ resistant to accumulation of $\mathrm{Fe}$ (III) salts}

Etching of steels in solutions of mineral acids is accompanied by the accumulation of $\mathrm{Fe}$ (III) salts due to dissolution of scale of Fe(II) salts formed in the reactions between the scale and the metal with the acid and their oxidation with air oxygen [51, 155]. For example, in an etching solution operating in periodical etching mode (initial $\mathrm{HCl}$ content $220 \mathrm{~g} / \mathrm{l}, t=40^{\circ} \mathrm{C}$, etching time up to $60 \mathrm{~min}$ ), when $3 / 4$ of the initial acid content is consumed, the concentration of $\mathrm{FeCl}_{3}$ may reach $0.1 \mathrm{M}$ [51]. Accumulation of $\mathrm{Fe}(\mathrm{III})$ salts 
results in the occurrence of an additional depolariser with a high oxidation potential $\left(E_{\mathrm{Fe}(\mathrm{III}) / \mathrm{Fe}(\mathrm{II})}^{0}=0.771 \mathrm{~V}[156]\right)$ in the solution, which substantially increases the system corrosivity toward steel. In acid solutions containing Fe(III), dissolution of steels occurs not only due to reaction of iron with the acid:

$$
\mathrm{Fe}+2 \mathrm{H}^{+}=\mathrm{Fe}^{2+}+\mathrm{H}_{2},
$$

but also as a result of a parallel reaction of the metal with the $\mathrm{Fe}(\mathrm{III})$ salt:

$$
\mathrm{Fe}+2 \mathrm{Fe}^{3+}=3 \mathrm{Fe}^{2+} .
$$

It is stated in [157] that in $\mathrm{HCl}$ solutions with high $\mathrm{FeCl}_{3}$ content, corrosion of steel occurs mostly because of the metal oxidation with $\mathrm{Fe}(\mathrm{III})$ cations, which can in practice suppress the evolution of hydrogen gas formed in the course of the reaction of steel with $\mathrm{HCl}$.

$\mathrm{Fe}$ (III) cations substantially decrease the protective action of CIs added to an etching solution [158]. It is noted that the presence of $\mathrm{FeCl}_{3}$ in inhibited hydrochloric acid solutions used at the plants of the oil producing sector drastically increase their corrosivity to steel equipment $[1,56]$. Among the reasons of reduced efficiency of CIs by $\mathrm{Fe}(\mathrm{III})$ cations we should note their removal from the corrosive medium due to coagulation [28] and the weak hindrance of $\mathrm{Fe}(\mathrm{III})$ reduction occurring diffusion mode by these compounds [126].

Almost no efficient way for reducing the adverse effect of $\mathrm{Fe}$ (III) on the corrosion of steels in acids is reported in literature. Addition of $15 \mathrm{~g} / \mathrm{S} \mathrm{SnCl}_{2} \cdot 2 \mathrm{H}_{2} \mathrm{O}$ is recommended for protection of steel in $5.9 \% \mathrm{HCl}+6.9 \mathrm{~g} / \mathrm{Fe}(\mathrm{III})\left(\right.$ at $\left.60^{\circ} \mathrm{C}\right)$. It slows down steel corrosion 18 -fold [159]. The poor performance of this additive is evident. It is very likely that its effect is based on the reduction of $\mathrm{Fe}$ (III) to $\mathrm{Fe}$ (II) by $\mathrm{Sn}$ (II) cations. As a result, the effect of the additive will be unstable due to its consumption. In addition, $\mathrm{SnCl}_{2}$ will be reduced on steel to $\mathrm{Sn}^{0}$, producing micro-galvanic pairs on its surface, which will result in local corrosion of a steel product during its further operation. To improve the efficiency of the PB-5 inhibitor for protection of steels in hot $4 \% \mathrm{HCl}$ solutions containing $1.5 \mathrm{~g} / \mathrm{FeCl}_{3}$, addition of urotropine is suggested, although its effect is small [158].

Improvement of CI protective action in solutions of acids containing $\mathrm{Fe}(\mathrm{III})$ salts is possible by means of reducing the total corrosivity of such a medium. This can be achieved using solutions of acids which upon dissociation generate anions capable of binding $\mathrm{Fe}(\mathrm{III})$ cations into strong complex ions with a weaker oxidation capability compared to $\mathrm{Fe}$ (III) aquacomplexes. Analysis of literature data on the stability of $\mathrm{Fe}(\mathrm{III})$ complexes with anions of mineral acids shows (Table 3) that solutions of $\mathrm{H}_{3} \mathrm{PO}_{4}$ and, in particular, $\mathrm{HF}$ are most promising in terms of reducing the oxidation capability of $\mathrm{Fe}$ (III) salts. It may be assumed that the oxidation capability of $\mathrm{Fe}$ (III) cations will be minimized in their solutions. 
Table 3. The instability constants $\left(\mathrm{p} K_{\mathrm{i}}\right)$ of $\mathrm{Fe}(\mathrm{III})$ complexes with some inorganic ligands. $t=20-30^{\circ} \mathrm{C}$.

\begin{tabular}{cccccccc}
\hline Ligands & $\mathbf{p} \boldsymbol{K}_{\mathbf{i 1}}$ & $\mathbf{p} \boldsymbol{K}_{\mathbf{i 1 . 2}}$ & $\mathbf{p} \boldsymbol{K}_{\mathbf{i 1 - 3}}$ & $\mathbf{p} \boldsymbol{K}_{\mathbf{i 1 - 4}}$ & $\mathbf{p} \boldsymbol{K}_{\mathbf{i 1}-\mathbf{5}}$ & $\mathbf{p} \boldsymbol{K}_{\mathbf{i 1}-\mathbf{6}}$ & $\mathbf{R e f .}$ \\
\hline $\mathrm{ClO}_{4}^{-}$ & 1.15 & - & - & - & - & - & 160 \\
& 1.0 & - & - & - & - & - & 161 \\
\hline $\mathrm{SO}_{4}^{2-}$ & 4.18 & 7.4 & - & - & - & - & 160 \\
\hline $\mathrm{HSO}_{4}^{-}$ & 2.02 & 5.38 & - & - & - & - & 162 \\
\hline $\mathrm{HPO}_{4}^{2-}$ & 3.5 & - & - & 9.15 & - & - & 163 \\
\hline $\mathrm{H}_{2} \mathrm{PO}_{4}^{-}$ & 9.75 & - & - & - & - & - & 160 \\
\hline $\mathrm{F}^{-}$ & 6.04 & 10.74 & 13.74 & 15.74 & 16.10 & -16.10 & 160 \\
\hline & 1.45 & 2.10 & 1.10 & -0.85 & - & - & 160 \\
$\mathrm{Cl}^{-}$ & 1.52 & 2.22 & - & - & - & - & 161 \\
\hline $\mathrm{Br}^{-}$ & 1.48 & 2.13 & 1.13 & - & - & - & 164 \\
\hline
\end{tabular}

In fact, a potentiometric study of $E_{\mathrm{Fe}(\mathrm{III}) / \mathrm{Fe}(\mathrm{II})}^{0}$ in various acids confirmed this. For mineral acids containing $\mathrm{Fe}(\mathrm{III})$, the oxidation capacity decreases in the series $\mathrm{HClO}_{4}>$ $\mathrm{HBr}>\mathrm{H}_{2} \mathrm{SO}_{4}>\mathrm{HCl}>\mathrm{H}_{3} \mathrm{PO}_{4}>\mathrm{HF}$ [165]. The prospects of practical use of $\mathrm{HF}$ for reducing the oxidation capability of media containing $\mathrm{Fe}(\mathrm{III})$ are very limited due to the high toxicity of this acid. In $\mathrm{H}_{3} \mathrm{PO}_{4}$ solutions $\left(20-95^{\circ} \mathrm{C}\right)$, the values of $E_{\mathrm{Fe}(\mathrm{III}) / \mathrm{Fe}(\mathrm{II})}$ are lower by $0.33-0.40 \mathrm{~V}$ than the standard value. Such a reduction in the system oxidation capability is sufficient for making some CIs efficient in steel protection in this medium. As discussed earlier, the combination of IFKhAN-92 and KNCS can efficiently inhibit corrosion of low-carbon steel in $\mathrm{H}_{3} \mathrm{PO}_{4}$ solutions containing $\mathrm{FePO}_{4}$ [126].

It is important that addition of $\mathrm{H}_{3} \mathrm{PO}_{4}$ to solutions of acids $\left(\mathrm{HCl}\right.$ and $\left.\mathrm{H}_{2} \mathrm{SO}_{4}\right)$, which do not considerably decrease the oxidation properties of $\mathrm{Fe}(\mathrm{III})$ cations, significantly decreases the oxidation capacity of these systems. In solutions of acid mixtures $(\mathrm{HCl}+$ $\mathrm{H}_{3} \mathrm{PO}_{4}$ or $\mathrm{H}_{2} \mathrm{SO}_{4}+\mathrm{H}_{3} \mathrm{PO}_{4}$ ) containing $\mathrm{Fe}(\mathrm{III})$ salts, the oxidation capability decreases with an increase in the relative content of $\mathrm{H}_{3} \mathrm{PO}_{4}$ in the system [165, 166]. In addition, examination of the system $\mathrm{H}_{2} \mathrm{SO}_{4}-\mathrm{H}_{3} \mathrm{PO}_{4}-\mathrm{H}_{2} \mathrm{O}-\mathrm{Fe}$ (III) by cyclic voltammetry (CVA) shows that binding $\mathrm{Fe}$ (III) ions into phosphate complexes significantly decreases the rate of their diffusion in a corrosion environment [167]. This plays an important role in inhibiting $\mathrm{Fe}(\mathrm{III})$ reduction on the surface of corroding steel because this process is diffusion-controlled [126].

The change in the properties of $\mathrm{HCl}$ and $\mathrm{H}_{2} \mathrm{SO}_{4}$ solutions containing $\mathrm{Fe}(\mathrm{III})$ after $\mathrm{H}_{3} \mathrm{PO}_{4}$ addition is sufficient to efficiently inhibit steel corrosion in such media by using CIs having 
high protective action. For example, in $2 \mathrm{M} \mathrm{H}_{2} \mathrm{SO}_{4}+\mathrm{H}_{3} \mathrm{PO}_{4}+0.05 \mathrm{M} \mathrm{Fe}(\mathrm{III})$, a formulation of $4.5 \mathrm{mM}$ IFKhAN-92 $+0.5 \mathrm{mM}$ KNCS efficiently inhibits the corrosion of low-carbon steel in solutions containing up to $50 \% \mathrm{H}_{2} \mathrm{SO}_{4}$ (Figure 7) [168]. In the same medium, the three-component formulation of $4.5 \mathrm{mM}$ IFKhAN-92 + 0.5 mM KNCS + 0.2 M urotropine protects low-carbon steel better. Satisfactory protective action of a three-component formulation of CIs on steel corrosion is observed in acid mixtures with higher $\mathrm{H}_{2} \mathrm{SO}_{4}$ content (up to $60 \%$ ) [169]. In $2 \mathrm{M} \mathrm{HCl}+\mathrm{H}_{3} \mathrm{PO}_{4}+0.05 \mathrm{M} \mathrm{Fe}(\mathrm{III})$, the formulation of $4.5 \mathrm{mM}$ IFKhAN-92 $+0.5 \mathrm{mM} \mathrm{KNCS}$ is not that efficient in inhibiting steel corrosion as in $2 \mathrm{M}$ $\mathrm{H}_{2} \mathrm{SO}_{4}+\mathrm{H}_{3} \mathrm{PO}_{4}+0.05 \mathrm{M} \mathrm{Fe}(\mathrm{III})$. However, addition of $4.5 \mathrm{mM}$ IFKhAN-92 $+0.5 \mathrm{mM}$ $\mathrm{KNCS}+0.2 \mathrm{M}$ urotropine to this corrosion medium allows one to provide satisfactory inhibition of steel corrosion in solutions of acid mixtures containing up to $60 \% \mathrm{HCl}$ [170]. In actual use, inhibited solutions of acid mixtures resistant to accumulation of Fe(III) are more practical than similar solutions of individual $\mathrm{H}_{3} \mathrm{PO}_{4}$ due to a reduction in the solution cost.



Figure 7. Steel corrosion inhibition factors for 08PS steel in $2 \mathrm{M} \mathrm{H}_{2} \mathrm{SO}_{4}+\mathrm{H}_{3} \mathrm{PO}_{4}$ and $2 \mathrm{M}$ $\mathrm{HCl}+\mathrm{H}_{3} \mathrm{PO}_{4}$ with addition of $0.05 \mathrm{M} \mathrm{Fe}$ (III) containing $4.5 \mathrm{mM}$ IFKhAN-92 $+0.5 \mathrm{mM}$ KNCS (1) and 4.5 mM IFKhAN-92 + 0.5 mM KNCS + 0.20 M urotropine (2), with various molar fractions of $\mathrm{H}_{3} \mathrm{PO}_{4}$ in solutions. Experiment duration -2 h. $t=60^{\circ} \mathrm{C}$.

The use of potentiometry and CVA methods for studying $\mathrm{HCl}-\mathrm{H}_{3} \mathrm{PO}_{4}-\mathrm{H}_{2} \mathrm{O}$ and $\mathrm{H}_{2} \mathrm{SO}_{4}-\mathrm{H}_{3} \mathrm{PO}_{4}-\mathrm{H}_{2} \mathrm{O}$ systems containing $\mathrm{Fe}(\mathrm{III})$ allowed the reasons of maintaining the protective effect in mixed CIs based on IFKhAN-92 in case of steel corrosion in such media to be found out. Phosphate ions bind the strong oxidant, i.e., Fe(III) cations present in the solution, into strong complexes. These complexes have a weaker oxidation capability and are less mobile compared to Fe(III) complexes existing in acid chloride or sulphate solutions. Adding $\mathrm{H}_{3} \mathrm{PO}_{4}$ affects the thermodynamics of the system by reducing its oxidation capability. This additive also changes the kinetic parameters of reduction of $\mathrm{Fe}$ (III) cations on steel, which is diffusion-controlled. A decrease in the diffusion rate of Fe(III) cations should slow down their reduction. Evidently, such a complex effect should be sufficient so that the mixed CI based on IFKhAN-92 can, jointly with the hindrance of proton reduction, suppress the reduction of Fe(III) cations. An important role in the 
observed effect belongs to IFKhAN-92 itself. It is capable of forming mono- and polymolecular protective layers on metals in solutions of acids. These layers are bound to a metal surface by strong chemical bonds, which allows a maximum protective effect to be obtained in such highly corrosive media as acids containing $\mathrm{Fe}$ (III) cations. Adding urotropine to such media additionally binds Fe(III) into complexes, thus reducing the content of its remaining non-complexed ions that are most corrosive to the metal.

Therefore, in the etching of steels or acid rinsing of steel equipment, in case of potential accumulation of $\mathrm{Fe}$ (III) salts that accelerate metal corrosion in such media, no solutions of individual mineral acids $\left(\mathrm{HCl}\right.$ or $\left.\mathrm{H}_{2} \mathrm{SO}_{4}\right)$ should be applied but mixtures on their basis containing no less than $40 \% \mathrm{H}_{3} \mathrm{PO}_{4}$ and an IFKhAN-92 + KNCS + urotropine combination (molecular ratio of components 9:1:400), because in such solutions steel corrosion due to its interaction with Fe(III) compounds is minimized.

\section{Conclusion}

$\mathrm{H}_{3} \mathrm{PO}_{4}$ solutions are widely used in various fields of technology. A more extensive practical use of this acid is mainly limited by its corrosivity toward some metals, especially at elevated $t$, as well as by the lack of efficient means of their inhibitor protection in this medium. The overwhelming majority of individual organic compounds and mixed CIs offered for protection of metals in phosphoric acid media are of low efficiency due to their weak adsorption on metal surfaces. Low adsorption capacity of these compounds on steels is a consequence of their competition with iron phosphates in this process.

A promising method for the protection of steels in $\mathrm{H}_{3} \mathrm{PO}_{4}$ media involves the use of formulations of triazoles with S-containing additives. Components of these mixtures can compete in adsorption with iron phosphates formed on the metal surface, and create polymolecular protective layers with high efficiency in inhibiting corrosion on it.

An important property of these protective layers is a strong chemical bond of the inhibitor molecules with the metal surface and with each other inside the layer. It is the formation of these layers on the steel surface that allows efficient protection of steels in highly corrosive media - hot $\mathrm{H}_{3} \mathrm{PO}_{4}$ solutions, as well as solutions of this acid containing $\mathrm{Fe}(\mathrm{III})$ cations.

Inhibited acid solutions resistant to accumulation of $\mathrm{Fe}$ (III) salts in them created with the use of phosphoric acid may become a new and promising field of application of $\mathrm{H}_{3} \mathrm{PO}_{4}$. Such solutions are necessary for etching steels or acid rinsing of steel equipment in case of potential accumulation of Fe(III) salts accelerating metal corrosion in such media.

\section{Acknowledgements}

The study was carried out under the Fundamental Scientific Research Program of the State Academies of Sciences for 2013-2020: "Development of the fundamental scientific foundations of the protective effect of metal corrosion inhibitors in gas and condensed media, nanocomposites, paints and conversion coatings" (State registration number AAAA-A18-118121090043-0). 


\section{References}

1. V.N. Glushchenko and M.A. Silin, Neftepromyslovaya khimiya. Vol. 4. Kislotnaya obrabotka skvazhyn (Oilfield chemistry. Vol. 4. Matrix acidizing), Ed.: I.T. Mishchenko, Intercontact Nauka, Moscow, 2010, 703 pp. (in Russian).

2. U.R. Evans, Metallic Corrosion, Passivity, and Protection, London, E. Arnold \& Co., 1937, $720 \mathrm{pp}$.

3. I.V. Nikol'skiy, Navodorozhivanie stali pri kislotnom travlenii (The hydrogenation of steel in acid etching), Ed.: S.A. Balezin, Prosvyashcheniye, Moscow, 1968, 136 pp. (in Russian).

4. V.F. Gorsheneva, I.G. Gorichev and N.G. Klyuchnikov, Osnovnye zakonomernosti travleniya okaliny $\mathrm{v}$ rastvorakh na osnove fosfornoi kisloty (The main regularities of scale etching in phosphoric acid-based solutions), Ingibitory korrozii metallov (Metal Corrosion Inhibitors), Ed.: S.A. Balezin, MGPI im. V.I. Lenina, Moscow, 1980, 21-28 (in Russian).

5. V.F. Gorshenova, Travlenie okaliny nizkouglerodistoi stali $\mathrm{v}$ rastvorakh fosfornoi kisloty, Dissertatsiya kandidata khimicheskikh nauk. (Etching of low-carbon steel scale in solutions of phosphoric acid, Dissertation of PhD in Chemistry), V.I. Lenin Moscow State Pedagogical Institute, Moscow, 1984, 195 pp. (in Russian).

6. A.V. Kuzin, I.G. Gorichev and Yu.A. Lainer, Stimulating Effect of Phosphate Ions on the Dissolution Kinetics of Iron Oxides in an Acidic Medium, Russian Metallurgy (Metally), 2013, 2013, no. 9, 652-657. doi: 10.1134/S0036029513090073

7. R.A. Lidin, V.A. Molochko and L.L. Andreyeva, Khimicheskie svoistva neorganicheskikh veshchestv, Uchebnoye posobiye dlya vuzov (Chemical properties of inorganic substances. A textbook for universities), KolosS, Moscow, 2003, 173-174 (in Russian).

8. N.V. Bukkolini, Fosfornaya kislota (Phosphoric acid), Khimicheskaya entsiklopediya, T. 5 (Chemical encyclopedia, V. 5), Eds.: N.S. Zefirov et al., Bol'shaya Rossiyskaya entsiklopediya, Moscow, 1998, 153-156 (in Russian).

9. S.P. Kochetkov, N.N. Smirnov and A.P. Il'in, Kontsentrirovaniye i ochistka ekstraktsionnoi fosfornoi kisloty (Concentration and purification of extraction phosphoric acid), Ivanovo State University of Chemistry and Technology, Ivanovo, 2007, 31-57 (in Russian).

10. V.V. Batrakov, V.P. Batrakov, L.N. Pivovarov and V.V. Sobol', Korroziya konstruktsionnykh materialov. Gazy $i$ neorganicheskie kisloty. Kniga 2. Neorganicheskiye kisloty (Corrosion of construction materials. Gases and inorganic acids. Book 2. Inorganic acids), Metallurgy, Moscow, 1990, 171-201 (in Russian).

11. Ya.G. Avdeev, M.V. Tyurina and Yu.I. Kuznetsov, Protection of low-carbon steel in phosphoric acid solutions by mixtures of a substituted triazole with sulfur-containing compounds, Int. J. Corros. Scale Inhib., 2014, 3, no. 4, 246-253. doi: 10.17675/23056894-2014-3-4-246-253 
12. S.V. Nesterenko and I.I. Ignatov, Korrozionnaya aktivnost' rastvoritelei nakipnykh otlozhenii teploobmennogo oborudovaniya (Corrosion activity of solvents for scale on heat exchange equipment), Kommunal'noye khozyaystvo gorodov, Nauchnotekhnicheskiy sbornik №74 (in "Municipal economy of cities”. Scientific and technical collection No. 74), Kharkiv, O.M. Beketov National University of Urban Economy in Kharkiv, 2007, 250-254 (in Russian).

13. F.B. Growcock and W.W. Frenier, Reaction Rate Studies for the Corrosion of Metals in Acids, I. Iron in Mineral Acids, Corrosion, 1983, 39, no. 5, 204-205. doi: 10.5006/1.3580837

14. A.S. Yaro, R.K. Wael and A.A. Khadom, Reaction kinetics of corrosion of mild steel in phosphoric acid, J. Univ. Chem. Technol. Metall., 2010, 45, no. 4, 443-448.

15. M.Yu. Archakova, Yu.P. Kostikov and K.I. Tikhonov, Korrozionnaya stoikost' legirovannykh stalei $\mathrm{v}$ goryachikh rastvorakh ortofosfornoi kisloty (Corrosion resistance of alloyed steels in hot solutions of orthophosphoric acid), Zhurnal prikladnoy khimii (Journal of Applied Chemistry), 1995, 68, no. 9, 1569-1571 (in Russian).

16. E.V. Filimonov, G.A. Ayuyan, A.I. Shcherbakov and T.A. Pisarenko, Korrozionnye i elektrokhimicheskie svoystva stali X18H10T v fosfornokislykh rastvorakh pri vysokoi temperature (Corrosion and electrochemical properties of X18H10T steel in phosphate solutions at high temperature), Zashch. met., 1999, 35, no. 6, 656-659 (in Russian).

17. E.V. Filimonov, Vliyanie ionov okislitel'nogo tipa na ustoychivost' passivnogo sostoyaniya stali KH18N10T v rastvorakh fosfornoi kisloty (The effect of oxidizing ions on the stability of the passive state of X18H10T steel in phosphoric acid solutions), Dissertatsiya kandidata khimicheskikh nauk ( $\mathrm{PhD}$ Chemistry Dissertation), A.N. Frumkin Institute of Physical Chemistry, Moscow, 2004, 186 pp. (in Russian).

18. Korroziya $i$ zashchita khimicheskoi apparatury. Spravochnoye rukovodstvo. T. 4. Proizvodstvo sernoi kisloty $i$ fosfornykh udobreniy (Corrosion and protection of chemical equipment. Reference Guide. Vol. 4. Production of sulfuric acid and phosphate fertilizers), Eds.: A.M. Sukhotin and V.S. Zotikov, Khimiya, Leningrad, 1970, 272 pp. (in Russian).

19. D.B. Bobkov， V.A. Kachanov， Yu.B. Danilov， E.K. Gvozdikova， T.E. Shepil', T.A. Balak and V.Yu. Kozin, Otsenka korrozionnoi stoikosti novykh konstruktsionnykh materialov $\mathrm{v}$ sredakh ekstraktsionnoy fosfornoi kisloty (Estimation of the corrosion resistance of new structural materials in environments of extraction phosphoric acid), Sbornik nauchnykh trudov "Vesnik Natsional'nogo tekhnicheskogo universiteta "Kharkovs'kiy politekhnicheskiy institut»: Khimiya, khimicheskaya tekhnologiya $i$ ekologiya (In the collection of scientific papers "Vesnik of National Technical University "Kharkiv Polytechnic Institute»": Chemistry, chemical technology and ecology), 2010, no. 15, 102-109 (in Russian).

20. Yu.I. Kuznetsov, Organic Inhibitors of Corrosion of Metals, New York, Plenum Press, 1996, 283 pp. 
21. Yu.I. Kuznetsov, Physicochemical aspects of metal corrosion inhibition in aqueous solutions, Russ. Chem. Rev., 2004, 73, no. 1, 75-87. doi: 10.1070/RC2004v073n01ABEH000864

22. N.N. Andreev and Yu.I. Kuznetsov, Physicochemical aspects of the action of volatile metal corrosion inhibitors, Russ. Chem. Rev., 2005, 74, no 8, 685-695. doi: 10.1070/RC2005v074n08ABEH001162

23. Yu.I. Kuznetsov and L.P. Kazansky, Physicochemical aspects of metal protection by azoles as corrosion inhibitors, Russ. Chem. Rev., 2008, 77, no 3, 219-232. doi: 10.1070/RC2008v077n03ABEH003753

24. Yu.I. Kuznetsov, Organic corrosion inhibitors: where are we now? A review. Part I. Adsorption, Int. J. Corros. Scale Inhib., 2015, 4, no. 4, 284-310. doi: 10.17675/2305$\underline{\text { 6894-2015-4-4-1 }}$

25. Yu.I. Kuznetsov, Organic corrosion inhibitors: where are we now? A review. Part II. Passivation and the role of chemical structure of carboxylates, Int. J. Corros. Scale Inhib., 2016, 5, no. 4, 282-318. doi: 10.17675/2305-6894-2016-5-4-1

26. Yu.I. Kuznetsov, Organic corrosion inhibitors: where are we now? A review. Part III. Passivation and the role of the chemical structure of organophosphates, Int. J. Corros. Scale Inhib., 2017, 6, no. 3, 209-239. doi: 10.17675/2305-6894-2017-6-3-1

27. Yu.I. Kuznetsov, Organic corrosion inhibitors: where are we now? A review. Part IV. Passivation and the role of mono- and diphosphonates, Int. J. Corros. Scale Inhib., 2017, 6, no. 4, 384-427. doi: 10.17675/2305-6894-2017-6-4-3

28. S.M. Reshetnikov, Ingibitory kislotnoi korrozii metallov (Metal Corrosion Inhibitors in Acids), Khimiya, Leningrad, 1986, 144 pp. (in Russian).

29. E.S. Ivanov, Ingibitory korrozii metallov v kislykh sredakh (Metal Corrosion Inhibitors in Acidic media), Metallurgiya, Moscow, 1986, 175 pp. (in Russian).

30. G. Schmitt, Application of Inhibitors for Acid Media, Br. Corros. J., 1984, 19, no 4, $165-176$.

31. Ya.G. Avdeev and Yu.I. Kuznetsov, Physicochemical aspects of inhibition of acid corrosion of metals by unsaturated organic compounds, Russ. Chem. Rev., 2012, 81, no 12, 1133-1145. doi: 10.1070/RC2012v081n12ABEH004292

32. N.I. Podobaev and Ya.G. Avdeev, A Review of Acetylene Compounds as Inhibitors of Acid Corrosion of Iron, Prot. Met., 2004, 40, no 1, 7-13.

33. Ya.G. Avdeev, Protection of Steel in Solutions of Mineral Acids Using $\alpha, \beta-$ Unsaturated Aldehydes, Ketones, and Azomethines, Prot. Met. Phys. Chem. Surf., 2015, 51, no. 7, 1140-1148. doi: 10.1134/S2070205115070023

34. R.K. Vagapov, Yu.I. Kuznetsov and A.V. Agafonkin, Ingibirovaniye korrozii metallov osnovaniyami Shiffa v rastvorakh mineral'nykh kislot (Inhibition of metals corrosion in solutions of mineral acids by Schiff bases), Korroz.: mater., zashch. (Corrosion: materials, protection), 2013, no. 4, 37-46 (in Russian). 
35. Ya.G. Avdeev, Nitrogen-containing six-membered heterocyclic compounds as corrosion inhibitors for metals in solutions of mineral acids - A review, Int. J. Corros. Scale Inhib., 2018, 7, no. 4, 460-497. doi: 10.17675/2305-6894-2018-7-4-1

36. K. Rasheeda, Vijaya D.P. Alva, P.A. Krishnaprasad and S. Samshuddin, Pyrimidine derivatives as potential corrosion inhibitors for steel in acid medium - An overview, Int. J. Corros. Scale Inhib., 2018, 7, no. 1, 48-61. doi: 10.17675/2305-6894-2018-7-1-5

37. M. Finšgar and J. Jackson, Application of corrosion inhibitors for steels in acidic media for the oil and gas industry: A review, Corros. Sci., 2014, 86, 17-41. doi: 10.1016/j.corsci.2014.04.044

38. A. Singh and M.A. Quraishi, Acidizing Corrosion Inhibitors: A Review, J. Mater. Environ. Sci., 2015, 6, no 1, 224-235.

39. S.A. Abd El-Maksoud, The Effect of Organic Compounds on the Electrochemical Behaviour of Steel in Acidic Media. A review, Int. J. Electrochem. Sci., 2008, 3, 528555.

40. S.A. Umoren and M.M. Solomon, Effect of halide ions on the corrosion inhibition efficiency of different organic species - A review, J. Ind. Eng. Chem., 2015, 21, 81100. doi: $10.1016 /$ j.jiec.2014.09.033

41. R.T. Loto, C.A. Loto and A.P.I. Popoola, Corrosion inhibition of thiourea and thiadiazole derivatives : A Review, J. Mater. Environ. Sci., 2012, 3, no 5, 885-894.

42. S.A. Umoren and M.M. Solomon, Recent Developments on the Use of Polymers as Corrosion Inhibitors - A Review, Open Mater. Sci. J., 2014, 8, 39-54.

43. G. Gece, Drugs: A review of promising novel corrosion inhibitors, Corros. Sci., 2011, 53, 3873-3898. doi: $10.1016 /$ j.corsci.2011.08.006

44. L. Hamadi, S. Mansouri, K. Oulmi and A. Kareche, The use of amino acids as corrosion inhibitors for metals: A review, Egypt. J. Pet., 2018, 27, no. 4, 1157-1165.

45. S. Hooshmand Zaferani, M. Sharifi, D. Zaarei and M. Reza Shishesaz, Application of eco-friendly products as corrosion inhibitors for metals in acid pickling processes - A review, J. Environ. Chem. Eng., 2013, 1, 652-657. doi: 10.1016/j.jece.2013.09.019

46. A. Singh, E.E. Ebenso and M.A. Quraishi, Corrosion Inhibition of Carbon Steel in $\mathrm{HCl}$ Solution by Some Plant Extracts, Int. J. Corros., 2012, 2012, Article ID 897430. doi: $\underline{10.1155 / 2012 / 897430}$

47. K. Xhanari and M. Finsgar, Organic corrosion inhibitors for aluminium and its alloys in acid solutions: a review, $R S C A d v ., 2016,6,62833-62857$. doi: $10.1039 / \mathrm{c} 6 \mathrm{ra1} 1818 \mathrm{f}$

48. Ya.G. Avdeev and M.V. Tyurina, Ingibitornaya zashchita metallov $\mathrm{v}$ rastvorakh fosfornoi kisloty (Inhibitory protection of metals in phosphoric acid solutions), Korroz.: mater., zashch. (Corrosion: materials, protection), 2016, no. 2, 7-19 (in Russian).

49. A.A. Khadom and S.N. Farhan, Corrosion inhibition of steel in phosphoric acid, Corros. Rev., 2018, 36, no. 3, 267-280. doi: 10.1515/corrrev-2017-0104

50. A.I. Altsibeeva and S.Z. Levin, Ingibitory korrozii metallov. Spravochnik (Metal Corrosion Inhibitors. Handbook), Khimiya, Leningrad, 1968, 264 pp. (in Russian). 
51. L.I. Antropov, E.M. Makushin and V.F. Panasenko, Ingibitory korrozii metallov (Metal Corrosion Inhibitors), Tehnika, Kiev, 1981, 183 pp. (in Russian).

52. L.N. Zimova, Kharakteristika ingibitorov kislotnoi korrozii chernykh metallov PKU-3 (Characteristics of inhibitors of acid corrosion of ferrous metals PKU-3), Ingibitory korrozii metallov (Metal corrosion inhibitors), Moscow, V.I. Lenin Moscow State Pedagogical Institute, 1980, 65-72 (in Russian).

53. N.I. Podobayev, N.L. Khar'kovskaya, E.V. Korotkikh and E.N. Ustinskiy, Ditiokarbamaty kak ingibitory kislotnoi korrozii (Dithiocarbamates as inhibitors of acid corrosion), Zashch. met., 1980, 16, no. 1, 73-75 (in Russian).

54. V.N. Glushchenko, A.V. Denisova and S.B. Yakimov, Opredelenie skorosti korrozii metallicheskikh materialov $\mathrm{v}$ kislotnykh sostavakh i effektivnosti zashchitnogo deystviya ingibitorov kislotnoi korrozii (Determination of the corrosion rate of metallic materials in acid formulations and the effectiveness of the protective action of acid corrosion inhibitors), Inzhenernaya praktika (Engineering practice), 2011, no. 1 (Special issue), 91-93 (in Russian).

55. S.V. Baranov, Ingibitornaya zashchita neftepromyslovogo oborudovaniya (Inhibitor protection of oilfield equipment), Inzhenernaya praktika (Engineering practice), 2011, no. 1 (Special issue), 79-81 (in Russian).

56. Ya.G. Avdeev, O.A. Kireeva and R.V. Kashkovsky, Ingibitornaya zashchita stalei v rastvorakh kislot (Inhibitor protection of steels in acid solutions), Korroz.: mater., zashch. (Corrosion: materials, protection), 2017, no. 2, 24-32 (in Russian).

57. N.I. Podobaev and Ya.G. Avdeev, Specific Effects of Propargyl Alcohol and Propargyl Chloride on an Iron Electrode in Inorganic Acids, Prot. Met., 2000, 36, no. 3, 251-257. doi: 10.1007/BF02758401

58. Ya.G. Avdeev, Yu.I. Kuznetsov and P.A. Belinsky, Zashchita stali ot kislotnoi korrozii ingibitorami na osnove produktov kondensatsii pervichnykh aminov $\mathrm{i}$ al'degidov (Protection of steel against acid corrosion by inhibitors based on the condensation products of primary amines and aldehydes), Korroz.: mater., zashch. (Corrosion: materials, protection), 2009, no. 11, 20-26 (in Russian).

59. Ya.G. Avdeev, Yu.I. Kuznetsov and O.O. Zel', Zashchita ot korrozii nizkouglerodistoi stali $\mathrm{v}$ rastvorakh mineral'nykh kislot ingibitorom IFKhAN-94 (Protection of low carbon steel from corrosion in solutions of mineral acids by IFKhAN-94 inhibitor), Praktika protivokorrozionnoi zashchity (Theory and Practice of Corrosion Protection), 2011, 59, no. 1, 8-13 (in Russian).

60. A. Zarrouk, H. Zarrok, R. Salghi, B. Hammouti, F. Bentiss, R. Touir and M. Bouachrine, Evaluation of N-containing organic compound as corrosion inhibitor for carbon steel in phosphoric acid, J. Mater. Environ. Sci., 2013, 4, no. 2, 177-192.

61. A. Ghanbari, M.M. Attar and M. Mahdavian, Corrosion inhibition performance of three imidazole derivatives on mild steel in $1 \mathrm{M}$ phosphoric acid, Mater. Chem. Phys., 2010, 124, 1205-1209. doi: 10.1016/j.matchemphys.2010.08.058 
62. L. Wang, Inhibition of mild steel corrosion in phosphoric acid solution by triazole derivatives, Corros. Sci., 2006, 48, 608-616. doi: 10.1016/j.corsci.2005.02.007

63. H. Vashisht, I. Bahadur, S. Kumar, K. Bhrara, D. Ramjugernath and G. Singh, Evaluation of Benzyl Triphenyl Phosphonium Chloride as Corrosion Inhibitor for Mild Steel in Phosphoric Acid, Int. J. Electrochem. Sci., 2014, 9, 2896-2911.

64. E.A. Noor, The inhibition of mild steel corrosion in phosphoric acid solutions by some $\mathrm{N}$-heterocyclic compounds in the salt form, Corros. Sci., 2005, 47, 33-55. doi: 10.1016/j.corsci.2004.05.026

65. M.A. Hegazy, Novel cationic surfactant based on triazole as a corrosion inhibitor for carbon steel in phosphoric acid produced by dihydrate wet process, J. Mol. Liq., 2015, 208, 227-236. doi: 10.1016/j.molliq.2015.04.042

66. L. Adardour, H. Lgaz, R. Salghi, M. Larouj, S. Jodeh, M. Zougagh, O. Hamed and M. Taleb, Corrosion Inhibition of Steel in phosphoric acid by Sulfapyridine: Experimental and Theoretical Studies, Pharm. Lett., 2016, 8, no. 4, 173-185.

67. K. Jayanthi, M. Sivaraju and K. Kannan, Inhibiting Properties of Morpholine as Corrosion Inhibitor for Mild Steel in $2 \mathrm{~N}$ Sulphuric Acid and Phosphoric Acid Medium, E-J. Chem., 2012, 9, no. 4, 2213-2225.

68. K.J. Orie, A.O. James and O. Akaranta, The Corrosion Inhibition of Mild Steel in $0.5 \mathrm{M}$ Phosphoric Acid and Crown Cork in Water By Folic Acid, International Journal of Science and Research (IJSR), 2015, 4, no. 9, 1380-1385.

69. M. Ozcan, R. Solmaz, G. Kardas and I. Dehri, Adsorption properties of barbiturates as green corrosion inhibitors on mild steel in phosphoric acid, Colloids Surf., A, 2008, 325, 57-63. doi: 10.1016/j.colsurfa.2008.04.031

70. M.A. Ameer and A.M. Fekry, Corrosion inhibition of mild steel by natural product compound, Prog. Org. Coat., 2011, 71, 343-349. doi: 10.1016/j.porgcoat.2011.04.001

71. M. Benabdellah, M. Benkaddour, B. Hammouti, M. Bendahhou and A. Aouniti, Inhibition of steel corrosion in $2 \mathrm{M} \mathrm{H}_{3} \mathrm{PO}_{4}$ by artemisia oil, Appl. Surf. Sci., 2006, 252, 6212-6217. doi: 10.1016/j.apsusc.2005.08.030

72. A.S. Yaro, A.A. Khadom and R.K. Wael, Apricot juice as green corrosion inhibitor of mild steel in phosphoric acid, Alexandria Eng. J., 2013, 52, 129-135. doi: 10.1016/j.aej.2012.11.001

73. M Sivaraju and K. Kannan, Inhibitive properties of plant extract (Acalypha indica L.) on mild steel corrosion in $1 \mathrm{~N}$ Phosphoric acid, Int. J. ChemTech Res., 2010, 2, no. 2, $1243-1253$.

74. S. Gomathi, V. Kumaravelan and D. Dhivya priya, Inhibition of mild steel corrosion in hydrochloric acid and phosphoric acid medium using Plectranthus Amboinicus (L) plant extract, Int. J. Adv. Res., 2015, 3, no. 5, 1307-1315.

75. X. Li, Sh. Deng, H. Fu and X.Xie, Synergistic inhibition effects of bamboo leaf extract/major components and iodide ion on the corrosion of steel in $\mathrm{H}_{3} \mathrm{PO}_{4}$ solution, Corros. Sci., 2014, 78, 29-42. doi: 10.1016/j.corsci.2013.08.025 
76. S. Noyel Victoria, P. Rohith and R. Manivannan, Psidium Guajava Leaf Extract as Green Corrosion Inhibitor for Mild steel in Phosphoric Acid, Int. J. Electrochem. Sci., 2015, 10, 2220-2238.

77. H. Zarrok， A. Zarrouk， R. Salghi， B. Hammouti， M. Elbakri， M. Ebn Touhami, F. Bentiss and H. Oudda, Study of a cysteine derivative as a corrosion inhibitor for carbon steel in phosphoric acid solution, Res. Chem. Intermed., 2014, 40, 801-815. doi: $10.1007 / \mathrm{s} 11164-012-1004-0$

78. X. Li, Sh. Deng and H. Fu, Allyl thiourea as a corrosion inhibitor for cold rolled steel in $\mathrm{H}_{3} \mathrm{PO}_{4}$ solution, Corros. Sci., 2012, 55, 280-288. doi: 10.1016/j.corsci.2011.10.025

79. M.A. Ameer, E. Khamis and G. Al-Senani, Adsorption Studies of the Effect of Thiosemicarbazides on the Corrosion of Steel in Phosphoric Acid, Adsorpt. Sci. Technol., 2000, 18, no. 3, 177-194.

80. A.A. Khulood, Al-Ola Abu and Y.Al-Nami Samar, 1-Benzoyl-4-phenyl-3thiosemicarbazide as Corrosion Inhibitor for Carbon Steel in $\mathrm{H}_{3} \mathrm{PO}_{4}$ Solution, Mod. Appl. Sci., 2011, 5, no. 3, 193-206.

81. T. Poornima, J. Nayak and A.N. Shetty, Effect of 4-(N,N-diethylamino)benzaldehyde thiosemicarbazone on the corrosion of aged $18 \mathrm{Ni} 250$ grade maraging steel in phosphoric acid solution, Corros. Sci., 2011, 53, 3688-3696. doi: 10.1016/j.corsci.2011.07.014

82. T. Poornima, J. Nayak and A.N. Shetty, Corrosion Inhibition of the Annealed $18 \mathrm{Ni}$ 250 Grade Maraging Steel in $0.67 \mathrm{M}$ Phosphoric Acid by 3,4Dimethoxybenzaldehydethiosemicarbazone, Chem. Sci. J., 2012, 2012, CSJ-69, 1-13.

83. L. Wang, Evaluation of 2-mercaptobenzimidazole as corrosion inhibitor for mild steel in phosphoric acid, Corros. Sci., 2001, 43, no. 12, 2281-2289. doi: 10.1016/S0010938X(01)00036-1

84. L. Wang, G.-J. Yin and J.-G. Yin, 2-Mercaptothiazoline and cetyl pyridinium chloride as inhibitors for the corrosion of a low carbon steel in phosphoric acid, Corros. Sci., 2001, 43, no. 6, 1197-1202. doi: 10.1016/S0010-938X(00)00138-4

85. L. Wang, Inhibiting effect of 2-mercaptopyrimidine on the corrosion of a low carbon steel in phosphoric acid, Corros. Sci., 2001, 43, no. 9, 1637-1644. doi: 10.1016/S0010-938X(00)00178-5

86. A.S. Fouda, M. Diab, A. El-Sonbati and Sh.A. Hassan, Benzothiazole derivatives as corrosion inh ibitors for carbon steel in $1 \mathrm{M}$ phosphoric acid $\left(\mathrm{H}_{3} \mathrm{PO}_{4}\right)$ solutions, Afr. J. Pure Appl. Chem., 2013, 7, no. 2, 67-78. doi: 10.5897/AJPAC2013.0482

87. H. Zarrok, A. Zarrouk, B. Hammouti, R. Salghi, C. Jama and F. Bentiss, Corrosion control of carbon steel in phosphoric acid by purpald - Weight loss, electrochemical and XPS studies, Corros. Sci., 2012, 64, 243-252. doi: 10.1016/j.corsci.2012.07.018

88. L. Wang, M.-J. Zhu, F.-Ch. Yang and Ch.-W. Gao, Study of a Triazole Derivative as Corrosion Inhibitor for Mild Steel in Phosphoric Acid Solution, Int. J. Corros., 2012, 2012, Article ID 573964. doi: $10.1155 / 2012 / 573964$ 
89. M. Benabdellah, A. Aouniti, A. Dafali, B. Hammouti, M. Benkaddour, A. Yahyi and A. Ettouhami, Investigation of the inhibitive effect of triphenyltin 2-thiophene carboxylate on corrosion of steel in $2 \mathrm{M} \mathrm{H}_{3} \mathrm{PO}_{4}$ solutions, Appl. Surf. Sci., 2006, 252, 8341-8347. doi: $10.1016 /$ j.apsusc.2005.11.037

90. I.R. Saad, A.M. Abdel-Gaber, G.O. Younes and B. Nsouli, Thiourea and N-Methylthiourea as Corrosion Inhibitors for Steel in Phosphoric Acid, J. Fail. Anal. Prevent., 2018, 18, 1293-1299. doi: 10.1007/s11668-018-0522-5

91. M.E. Belghiti, S. Tighadouini, Y. Karzazi, A. Dafali, B. Hammouti, S. Radi and R. Solmaz, New hydrazine derivatives as corrosion inhibitors for mild steel protection in phosphoric acid medium. Part A: Experimental study, J. Mater. Environ. Sci., 2016, 7, no. $1,337-346$.

92. S.T. Arab and A.M. Al-Turkustani, Corrosion Inhibition of Steel in Phosphoric Acid by Phenacyldimethyl Sulfonium Bromide and some of its p-Substituted Derivatives, Port. Electrochim. Acta, 2006, 24, no. 4, 53-69.

93. D. Ben Hmamou， R. Salghi， A. Zarrouk， H. Zarrok， M. Assouag， B. Hammouti, S.S. Al-Deyab and M. El Hezza, Inhibition of carbon steel corrosion in phosphoric acid solution by Alizarin red, Pharm. Lett., 2013, 5, no. 2, 135-142.

94. A. Ghanbari, M.M. Attar and M. Mahdavian, Acetylacetonate Complexes as New Corrosion Inhibitors in Phosphoric Acid Media: Inhibition and Synergism Study, Prog. Color, Color. Coat., 2009, 2, 115-122.

95. M. Benabdellah, R. Touzani, A. Dafali, B. Hammouti, S. El Kadiri, Ruthenium-ligand complex, an efficient inhibitor of steel corrosion in $\mathrm{H}_{3} \mathrm{PO}_{4}$ media, Mater. Lett., 2007, 61, 1197-1204. doi: 10.1016/j.matlet.2006.06.082

96. L.M. Alaoui, S. Kertit, A. Bellaouchou, A. Guenbour, A. Benbachir and B. Hammouti, Phosphate of Aluminum as Corrosion Inhibitor for Steel in $\mathrm{H}_{3} \mathrm{PO}_{4}$, Port. Electrochim. Acta, 2008, 26, no 4, 339-347.

97. E.V. Filimonov and A.I. Shcherbakov, Inhibiting the corrosion of stainless steel in phosphoric acid, Prot. Met., 2000, 36, no 3, 296-298. doi: 10.1007/BF02758411

98. E.V. Filimonov and A.I. Shcherbakov, The Effect of Products of Nitrate Ion Reduction on the Kinetics of Electrode Reactions on Stainless Steel, Prot. Met., 2001, 37, no. 6, 539-542. doi: 10.1023/A:1012859312143

99. S. Skal, Y. Kerroum, Y. El Aoufir, A. Guenbour, A. Bellaouchou, H. Tabyaoui and H. Idrissi, Corrosion inhibition of austenitic stainless steel by clay in polluted phosphoric acid with presence of SiC abrasif, MATEC Web Conf., 2018, 149, 01049. doi: $10.1051 /$ matecconf/201814901049 
100. N.I. Podobaev and V.V. Vasil'yev, Issledovanie zashchitnogo deystviya azotsoderzhashchikh i atsetilenovykh ingibitorov korrozii stali i ikh smesei v solyanoi kislote v zavisimosti ot temperatury $\left(\right.$ do $250^{\circ} \mathrm{C}$ ) i davleniya (do $700 \mathrm{~atm}$.) (Study of the protective effect of nitrogen-containing and acetylene-based corrosion inhibitors of steel and their mixtures in hydrochloric acid as a function of temperature (up to $250^{\circ} \mathrm{C}$ ) and pressure (up to $700 \mathrm{~atm}$.)), Ingibitory korrozii metallov (Metal corrosion inhibitors), MGPI im. V.I. Lenina, Moscow, 1969, Issue 3, 72-82 (in Russian).

101. A.A. Khadom and A.S. Yaro, Protection of Low Carbon Steel in Phosphoric Acid by Potassium Iodide, Prot. Met. Phys. Chem. Surf., 2011, 47, no. 5, 662-669. doi: $\underline{10.1134 / \mathrm{S} 2070205111050078}$

102. X. Li, Sh. Deng and H. Fu, Synergistic inhibition effect of 6-benzylaminopurine and iodide ion on the corrosion of cold rolled steel in $\mathrm{H}_{3} \mathrm{PO}_{4}$ solution, Corros. Sci., 2011, 53, 3704-3711. doi: $10.1016 /$ j.corsci.2011.07.016

103. Q. Qu, Z. Hao, S. Jiang, L. Li and W. Bai, Synergistic inhibition between dodecylamine and potassium iodide on the corrosion of cold rolled steel in $0.1 \mathrm{M}$ phosphoric acid, Mater. Corros., 2008, 59, no. 11, 883-888. doi: 10.1002/maco.200804176

104. X. Li, Sh. Deng and H. Fu, Benzyltrimethylammonium iodide as a corrosion inhibitor for steel in phosphoric acid produced by dihydrate wet method process, Corros. Sci., 2011, 53, 664-670. doi: 10.1016/j.corsci.2010.10.013

105. L. Tang, X. Li, G. Mu, L. Li and G. Liu, Synergistic effect between 4-(2pyridylazo)resorcin and chloride ion on the corrosion of cold rolled steel in $1.0 \mathrm{M}$ phosphoric acid, Appl. Surf. Sci., 2006, 253, 2367-2372. doi: 10.1016/j.apsusc.2005.04.059

106. X. Li, L. Tang, H. Liu, G. Mu and G. Liu, Influence of halide ions on inhibitive performance of cetyl trimethyl ammonium bromide in various concentrations of phosphoric acid for cold rolled steel, Mater. Lett., 2008, 62, 2321-2324. doi: 10.1016/j.matlet.2007.11.080

107. A.S. Fouda, M. Abdallah and Z. El-Badrawy, Some hydrazone derivatives as corrosion inhibitors for iron in 3,5\% $\mathrm{H}_{3} \mathrm{PO}_{4}$ solution, Afr. J. Pure Appl. Chem., 2011, 5, no. 8, 224-236.

108. X. Li, Sh. Deng, H, Fu and G. Mu, Synergistic inhibition effect of rare earth cerium(IV) ion and sodium oleate on the corrosion of cold rolled steel in phosphoric acid solution, Corros. Sci., 2010, 52, 1167-1178. doi: 10.1016/j.corsci.2009.12.017

109. X. Li, Sh. Deng and H. Fu, Synergistic inhibition effect of red tetrazolium and uracil on the corrosion of cold rolled steel in $\mathrm{H}_{3} \mathrm{PO}_{4}$ solution: Weight loss, electrochemical, and AFM approaches, Mater. Chem. Phys., 2009, 115, 815-824. doi: 10.1016/j.matchemphys.2009.02.025

110. E.V. Filimonov and A.I. Shcherbakov, On the Effect of Copper and Nitrate Ions on the Stainless Steel Corrosion in Phosphoric Acid, Prot. Met., 2002, 38, no. 1, 95-96. doi: 10.1023/A:1013821321734 
111. E.V. Filimonov and A.I. Shcherbakov, Catalytic Effect of Copper Ions on Nitrate Reduction, Prot. Met., 2004, 40, no. 3, 280-285. doi: 10.1023/B:PROM.0000028923.12984.8c

112. A. Bellaouchou, B. Kabkab, A. Guenbour and A. Ben Bachir, Corrosion inhibition under heat transfer of 904L stainless steel in phosphoric acid by benzotriazole, Prog. Org. Coat., 2001, 41, 121-127.

113. E.E. Kravtsov, A.V. Tarasova, N.N. Starkova, S.A. Gorbachev, S.N. Malyavin and T.S. Kondratenko, Ingibitor korrozii metallov $\mathrm{v}$ sernoi, solyanoi i ortofosfornoi kislotakh (Inhibitor of corrosion of metals in sulfuric, hydrochloric and phosphoric acids), RF Patent, 2170288, C 23 F 11/04,10.07.2001 (in Russian).

114. E.E. Kravtsov, R.R. Svetasheva, D.A. Shamyanova, N.N. Starkova, S.G. Kaliev and T.S. Kondratenko, Ingibitor korrozii metallov $\mathrm{v}$ sernoi, solyanoi i ortofosfornoi kislotakh (Inhibitor of corrosion of metals in sulfuric, hydrochloric and phosphoric acids), RF Patent, 2203981, $C 23$ F 11/04, 10.05 .2003 (in Russian).

115. E.E. Kravtsov, A.M. Shumeev, L.S. Jankovskij, D.S. Jankovskij, N.N. Starkova and T.S. Kondratenko, Corrosion inhibitor in sulfuric, hydrochloric and orthophosphoric acids, $R F$ Patent, 2265675 Cl, C 23 F 11/04, 10.12.2005.

116. E.E. Kravtsov， I.A. Burlak, R.O. Kas'janov, O.P. Fomenko, N.N. Starkova, N.P. Ogorodnikova, S.A. Gorbachev, A.B. Polovnikov and A.P. Kondratenko, Inhibiting agent for corrosion inhibition of metals in sulfuric, hydrochloric and orthophosphoric acids, RF Patent, 2320777 C1, C23F 11/04, 27.03.2008.

117. E.E. Kravtsov, U.A. Balamedova, A.S. Sidorova, R.A. Idiatulin, A.V. Petrovskij, N.N. Starkova, N.P. Ogorodnikova and T.S. Kondratenko, Corrosion metal inhibitor in sulphuric, hydrochloric and orthophosphoric acids, RF Patent, $2324766 \mathrm{Cl}, \mathrm{C} 23 \mathrm{~F}$ $11 / 04,20.05 .2008$.

118. E.E. Kravtsov， I.A. Sasonov， R.A. Dojnikov， N.N. Starkova， N.P. Ogorodnikova, N.T. Limonova and T.S. Kondratenko, Inhibitor for corrosion of metals in sulphuric, hydrochloric and orthophosphoric acid, RF Patent, 2330123 Cl, C23F 11/04, 27.07.2008.

119. E.E. Kravtsov， A.M. Stepkin， A.R. Jafarova， D.V. Slobodjan， N.N. Starkova, N.P. Ogorodnikova and A.P. Kondratenko, Inhibitor of metal corrosion in sulphuric, hydrochloric and orthophosphoric acids, RF Patent, $2385362 \mathrm{Cl}, \mathrm{C} 23 \mathrm{~F}$ 11/04, 27.03.2010.

120. D.A. Vostrikova， I.A. Burlak， E.E. Kravtsov， D.T. Masalimova， N.N. Starkova, M.D. Aptekar', N.P. Ogorodnikova and T.S. Kondratenko, Inhibitor of corrosion of metals in sulphuric, hydrochloric and orthophosphoric acids, RF Patent, $2418099 \mathrm{Cl}$, C23F 11/04, 10.05.2011.

121. M.S.S. Morad, Abo El-Hagag A. Hermas and M.S. Abdel Aal, Effect of amino acids containing sulfur on the corrosion of mild steel in phosphoric acid solutions polluted with $\mathrm{Cl}^{-}, \mathrm{F}^{-}$and $\mathrm{Fe}^{3+}$ ions - behaviour near and at the corrosion potential, J. Chem. Technol. Biotechnol., 2002, 77, 486-494. doi: 10.1002/jctb.588 
122. Ya.G. Avdeev, M.V Tyurina, Yu.I. Kuznetsov, Kh.S. Shikhaliyev, N.V. Stolpovskaya and A.S. Peregudova, Vliyaniye proizvodnykh N-(2-khlorfenil)-1,3,5-triazin-2,4diamina na elektrodnye reaktsii i korroziyu nizkouglerodistoi stali $\mathrm{v}$ mineral'nykh kislotakh (Effect of $\mathrm{N}$-(2-chlorophenyl)-1,3,5-triazine-2,4-diamine derivatives on electrode reactions and corrosion of low carbon steel in mineral acids), Korroz.: mater., zashch. (Corrosion: materials, protection), 2015, no. 10, 32-38 (in Russian).

123. L.G. Kors, N.V. Kors and Yu.S. Pavelkova, Vybor effektivnykh ingibitorov dlya travleniya stali $\mathrm{v}$ fosfornoi kislote (Selection of effective inhibitors for steel pickling in phosphoric acid), Izvestiya Kaliningradskogo gosudarstvennogo tekhnicheskogo universiteta (Proceedings of Kaliningrad State Technical University), 2011, no. 20, 76-83.

124. Ya.G. Avdeev, Yu.I. Kuznetsov and M.V. Tyurina, Zashchita nizkouglerodistoi stali v rastvorakh fosfornoi kisloty ingibitorom IFKhAN-92. Ch. 1 (Protection of low carbon steel in solutions of phosphoric acid inhibitor IFKhAN-92. Part 1), Korroz.: mater., zashch. (Corrosion: materials, protection), 2012, no. 5, 22-26 (in Russian).

125. Ya.G. Avdeev, M.V. Tyurina and Yu.I. Kuznetsov, Ob ingibirovanii korrozii nizkouglerodistoi stali $\mathrm{v}$ fosfornokislykh sredakh proizvodnym triazola (On the inhibition of corrosion of low carbon steel in phosphate environments by a triazole derivative), Tambov University Reports. Series: Natural and Technical Sciences, 2013, 18, no. 5, 2258-2261 (in Russian).

126. Ya.G. Avdeev, M.V. Tyurina and Yu.I. Kuznetsov, Zashchita nizkouglerodistoi stali v rastvore fosfornoi kisloty ingibitorom IFKHAN-92. Ch. 3. Vliyaniye kationov zheleza (Protection of low carbon steel in a solution of phosphoric acid by IFHAN-92 inhibitor. Part 3. The effect of iron cations), Korroz.: mater., zashch. (Corrosion: materials, protection), 2014, no. 1, 18-25 (in Russian).

127. M.A. Amin, Q. Mohsen and O.A. Hazzazi, Synergistic effect of $\mathrm{I}^{-}$ions on the corrosion inhibition of $\mathrm{Al}$ in $1.0 \mathrm{M}$ phosphoric acid solutions by purine, Mater. Chem. Phys., 2009, 114, 908-914. doi: 10.1016/j.matchemphys.2008.10.057

128. A.S. Fouda, M. Abdallah and M. Eissa, Corrosion inhibition of Aluminum in $1 \mathrm{M}$ phosphoric acid solutions using some Chalcones derivatives and synergistic action with halide ions, Afr. J. Pure Appl. Chem., 2013, 7, no. 12, 394-404. doi: 10.5897/AJPAC2013.0534

129. D. Prabhu and P. Rao, Corrosion inhibition of 6063 aluminum alloy by Coriandrum sativum L. seed extract in phosphoric acid medium, J. Mater. Environ. Sci., 2013, 4, no. $5,732-743$.

130. D. Prabhu and P. Rao, Coriandrum sativum L. - A novel green inhibitor for the corrosion inhibition of aluminium in $1.0 \mathrm{M}$ phosphoric acid solution, J. Environ. Chem. Eng., 2013, 1, 676-683. doi: 10.1016/j.jece.2013.07.004

131. M.S. Uwineza, M. Essahli and A. Lamiri, Corrosion Inhibition of Aluminium in $2 \mathrm{M}$ Phosphoric Acid Using the Essential Oil of Mentha Pulegium Leaves, Port. Electrochim. Acta, 2016, 34, no. 1, 53-62. doi: 10.4152/pea.201601053 
132. X. Li and Sh. Deng, Inhibition effect of Dendrocalamus brandisii leaves extract on aluminum in $\mathrm{HCl}, \mathrm{H}_{3} \mathrm{PO}_{4}$ solutions, Corros. Sci., 2012, 65, 299-308. doi: 10.1016/j.corsci.2012.08.033

133. J.D. Talati and J.M. Pandya, Anilines as corrosion inhibitors for an aluminium-copper alloy in phosphoric acid, Corros. Sci., 1976, 16, no 9, 603-612. doi: 10.1016/S0010938X(76)80019-4

134. X. Li, Sh. Deng and H. Fu, Sodium molybdate as a corrosion inhibitor for aluminium in $\mathrm{H}_{3} \mathrm{PO}_{4}$ solution, Corros. Sci., 2011, 53, 2748-2753. doi: 10.1016/j.corsci.2011.05.002

135. M.A. Ameer, A.A. Ghoneim and A.M. Fekry, Electrochemical Corrosion Inhibition of Al-Si Alloy in Phosphoric Acid, Int. J. Electrochem. Sci., 2012, 7, 4418-4431.

136. M.A. Ameer, A.A. Ghoneim and A.M. Fekry, Electrochemical Corrosion Inhibition of Al-Alloy in Phosphoric Acid, Chem. Mater. Res., 2012, 2, no. 1, 41-55.

137. R.T. Vashi avd D. Naik, Aniline as Corrosion Inhibitor for Zinc in Phosphoric acid, Int. J. ChemTech Res., 2011, 3, no. 2, 864-869.

138. R.T. Vashi avd D. Naik, Hexamine as Corrosion Inhibitors for Zinc in Phosphoric Acid, E-J. Chem., 2010, 7(S1), S1-S6.

139. R.T. Vashi avd D. Naik, 4-Aminoantipyrine as corrosion inhibitor for zinc in phosphoric acid, Pharma Chem., 2012, 4, no. 4, 1471-1476.

140. M. Boulkroune and A. Chibani, 2-Thiophene Carboxaldehyde as Corrosion Inhibitor for Zinc in Phosphoric Acid Solution, Chem. Sci. Trans., 2012, 1, no. 2, 355-364. doi: 10.7598/cst2012.4730

141. L. Wang, Ji.-X. Pu and H.-Ch. Luo, Corrosion inhibition of zinc in phosphoric acid solution by 2-mercaptobenzimidazole, Corros. Sci., 2003, 45, no. 4, 677-683. doi: 10.1016/S0010-938X(02)00145-2

142. Ya.G. Avdeev and Yu.I. Kuznetsov, Zashchita tsvetnykh metallov $\mathrm{v}$ rastvorakh mineral'nykh kislot ingibitorom IFKhAN-92 (Protection of non-ferrous metals in solutions of mineral acids by IFhAN-92 inhibitor), Korroz.: mater., zashch. (Corrosion: materials, protection), 2011, no. 5, 30-33 (in Russian).

143. M. Lashgari, M.-R. Arshadi and M. Biglar, Comparative Studies of Some Heterocyclic Compounds as Corrosion Inhibitors of Copper in Phosphoric Acid Media, Chem. Eng. Comm., 2010, 197, 1303-1314. doi: 10.1080/00986441003622887

144. M. Scendo and J. Uznanska, Inhibition Effect of 1-Butyl-4-Methylpyridinium Tetrafluoroborate on the Corrosion of Copper in Phosphate Solutions, Int. J. Corros., 2011, 2011, Article ID 761418. doi: $10.1155 / 2011 / 761418$

145. F. Mounir, S. El Issami, Lh. Bazzi, R. Salghi, L. Bammou, L. Bazzi, A. Chihab Eddine and O. Jbara, Copper Corrosion Behavior in Phosphoric Acid Containing Chloride and its Inhibition by Artemisia Oil, Int. J. Res. Rev. Appl. Sci., 2012, 13, no. 2, 574-587.

146. R.S. Kumar and V. Chandrasekaran, Sargassum wightii Extract as a Green Inhibitor for Corrosion of Brass in $0.1 \mathrm{~N}$ Phosphoric Acid Solution, Orient. J. Chem., 2015, 31, no. 2, 939-949. doi: 10.13005/ojc/310239 
147. L.Ya. Gurvich, E.V. Butkova, V.B. Laschevsky and L.I. Shubadeeva, Sostav dlya udaleniya produktov atmosfernoy korrozii s poverkhnosti nerzhaveyushchikh stalei (Composition for removing atmospheric corrosion products from the surface of stainless steels), RF Patent, 2105085, C23G1/08, 20.02.1998 (in Russian).

148. V.V. Makarov, A.A. Petrykin, V.P. Barannik, A.V. Muratov, A.I. Korolev and A.V. Shamonina, Cold-resistant rust converter, RF Patent, 2263159 C1, C 23 C 22/00, 27.10.2005.

149. G.G. Berdnikova and I.S. Provotorov, Vliyanie dobavok fosfornoi kisloty na korroziyu khromonikelevoi nerzhaveyushchei stali Kh18N10T v solyanokislykh rastvorakh (The effect of phosphoric acid additives on the corrosion of nickel-chromium stainless steel Kh18N10T in hydrochloric acid solutions), Tambov University Reports. Series: Natural and Technical Sciences, 2011, 16, no. 2, 558-561 (in Russian).

150. M. Oki, E. Charles, C. Alaka and T.K. Oki, Corrosion Inhibition of Mild Steel in Hydrochloric Acid by Tannins from Rhizophora Racemosa, Mater. Sci. Appl., 2011, 2, 592-595. doi: $10.4236 / \mathrm{msa} .2011 .26079$

151. M.S. Morad, Infuence of propargyl alcohol on the corrosion behaviour of mild steel in $\mathrm{H}_{3} \mathrm{PO}_{4}$ solutions, Mater. Chem. Phys., 1999, 60, 188-195. doi: $\underline{10.1016 / \mathrm{S} 0254-}$ 0584(99)00090-5

152. Ya.G. Avdeev, A.Yu. Luchkin, M.V. Tyurina and Yu.I. Kuznetsov, Adsorption of IFKhAN-92 Corrosion Inhibitor From Acidic Phosphate Solution on Low Carbon Steel, Prot. Met. Phys. Chem. Surf., 2017, 53, no. 7, 1247-1251. doi: 10.1134/S2070205117070048

153. Ya.G. Avdeev, M.V. Tyurina, Yu.I. Kuznetsov, Yu.E. Pronin and L.P. Kazanskii, Zashchita nizkouglerodistoi stali v rastvorakh fosfornoi kisloty ingibitorom IFKhAN92. Ch. 2. (Protection of low-carbon steel in solutions of phosphoric acid by IFhAN-92 inhibitor. Part 2), Korroz.: mater., zashch. (Corrosion: materials, protection), 2013, no. 6, 17-23 (in Russian).

154. Ya.G. Avdeev and M.V. Tyurina, Vliyaniye ingibitora IFKhAN-92 na elektrodnyye reaktsii i korroziyu nizkouglerodistoi stali $\mathrm{v}$ rastvore fosfornoi kisloty (Effect of IFhAN-92 inhibitor on electrode reactions and corrosion of low-carbon steel in phosphoric acid solution), Korroz.: mater., zashch. (Corrosion: materials, protection), 2015, no. 6, 19-25 (in Russian).

155. A.S. Afanasyev and G.M. Kvedchenya, Kinetika sernokislotnogo travleniya nizkouglerodistoi stali, pokrytoy okalinoy (Kinetics of sulfuric acid etching of mild steel covered with scale), Travleniye $i$ obezzhirivanie trub iz stalei i splavov. Materialy nauchno-tekhnicheskogo seminara po travleniyu $i$ obezzhirivaniyu trub iz stalei $i$ splavov (Etching and degreasing of pipes made of steel and alloys. Materials of a scientific and technical seminar on etching and degreasing of pipes made of steels and alloys), Metallurgiya, Moscow, 1967, 51-55 (in Russian).

156. Techniques of electrochemistry: Electrode Processes. V. 1., Eds.: E. Yeager and A.J. Salkind, John Wiley \& Sons Inc., New York, 1972, 592 pp. 
157. Yu.V. Balaban-Irmenin and L.A. Litvinova, O vliyanii ionov trekhvalentnogo zheleza na protsess korrozii stalei $\mathrm{v}$ kislykh sredakh (On the effect of ferric ions on the corrosion process of steels in acidic environments), Zashch. met., 1978, 14, no 4, 475477 (in Russian).

158. F.B. Glikina, E.S. Bulavina and N.I. Podobaev, Zashchita ot korrozii stali marok St 1 i EI $531 \mathrm{v}$ razbavlennykh rastvorakh solyanoi kisloty v prisutstvii khlornogo zheleza (Corrosion protection of St 1 and EI 531 steels in dilute solutions of hydrochloric acid in the presence of ferric chloride), Ingibitory korrozii metallov. Sbornik No. 3 (Metal Corrosion Inhibitors. Vol. 3), V.I. Lenin Moscow State Pedagogical Institute, Moscow, 1969, 190-195 (in Russian).

159. H. Leidheiser, A review of Proposed Mechanisms for Corrosion Inhibitor and Passivation by Metallic Cations, Corrosion, 1980, 36, no. 7, 339-345.

160. Yu.Yu. Lurie, Spravochnik po analiticheskoy khimii (Handbook of Analytical Chemistry), Khimiya, Moscow, 1971, 255-265 (in Russian).

161. X. Zhu, D.K. Nordstrom, R.B. McCleskey, R. Wang and X. Lu, Thermodynamic properties in the $\mathrm{Fe}(\mathrm{II})-\mathrm{Fe}(\mathrm{III})-\mathrm{As}(\mathrm{V})-\mathrm{HClO}_{4}-\mathrm{H}_{2} \mathrm{O}$ and $\mathrm{Fe}(\mathrm{II})-\mathrm{Fe}(\mathrm{III})-\mathrm{As}(\mathrm{V})-\mathrm{HCl}-\mathrm{H}_{2} \mathrm{O}$ systems from 5 to $90^{\circ} \mathrm{C}$, Chem. Geol., 2017, 460, 37-45. doi: 10.1016/i.chemgeo.2017.04.010

162. J.M. Casas, G. Crisóstomo and L. Cifuentes, Speciation of the $\mathrm{Fe}(\mathrm{II})-\mathrm{Fe}(\mathrm{III})-\mathrm{H}_{2} \mathrm{SO}_{4}-$ $\mathrm{H}_{2} \mathrm{O}$ system at 25 and $50^{\circ} \mathrm{C}$, Hydrometallurgy, 2005, 80, no 4, 254-264. doi: 10.1016/j.hydromet.2005.07.012

163. G. Yue, L. Zhao, O.G. Olvera and E. Asselin, Speciation of the $\mathrm{H}_{2} \mathrm{SO}_{4}-\mathrm{Fe}_{2}\left(\mathrm{SO}_{4}\right)_{3}-$ $\mathrm{FeSO}_{4}-\mathrm{H}_{2} \mathrm{O}$ systemand development of an expression to predict the redox potential of the $\mathrm{Fe}^{3+} / \mathrm{Fe}^{2+}$ couple up to $150^{\circ} \mathrm{C}$, Hydrometallurgy, 2014, 147-148, 196-209. doi: 10.1016/i.hydromet.2014.05.008

164. H. Majima and Y. Awakura, Water and Solute Activities of $\mathrm{H}_{2} \mathrm{SO}_{4}-\mathrm{Fe}_{2}\left(\mathrm{SO}_{4}\right)_{3}-\mathrm{H}_{2} \mathrm{O}$ and $\mathrm{HCl}-\mathrm{FeCl}_{3}-\mathrm{H}_{2} \mathrm{O}$ Solution Systems: Part I. Activities of Water, Metall. Trans. B, 1985, 16, 433-439.

165. Ya.G. Avdeev, T.E. Andreeva and Yu.I. Kuznetsov, A potentiometric study of an $\mathrm{H}_{2} \mathrm{SO}_{4}-\mathrm{H}_{3} \mathrm{PO}_{4}-\mathrm{H}_{2} \mathrm{O}$ system containing $\mathrm{Fe}(\mathrm{III})$ and $\mathrm{Fe}(\mathrm{II})$ cations, Int. J. Corros. Scale Inhib., 2018, 7, no 3, 366-375. doi: 10.17675/2305-6894-2018-7-3-7

166. Ya.G. Avdeev, T.E. Andreeva, A.V. Panova and Yu.I. Kuznetsov, Effect of anionic composition of solutions of mineral acids containing $\mathrm{Fe}(\mathrm{III})$ on their oxidizing properties, Int. J. Corros. Scale Inhib., 2019, 8, no 1, 139-149. doi: 10.17675/23056894-2019-8-1-12

167. Ya.G. Avdeev, T.E. Andreeva, A.V. Panova and E.N. Yurasova, A study of the $\mathrm{H}_{2} \mathrm{SO}_{4}-\mathrm{H}_{3} \mathrm{PO}_{4}-\mathrm{H}_{2} \mathrm{O}-\mathrm{Fe}(\mathrm{III})$ system by cyclic voltammetry, Int. J. Corros. Scale Inhib., 2019, 8, no 2, 411-421. doi: 10.17675/2305-6894-2019-8-2-18 
168. Ya.G. Avdeev, O.A. Kireeva, Yu.I. Kuznetsov and I.G. Gorichev, Effect of the anionic composition of acidic solutions containing Fe(III) on the protection of low-carbon steel by a triazole inhibitor, Int. J. Corros. Scale Inhib., 2016, 5, no. 4, 333-346. doi: 10.17675/2305-6894-2016-5-4-4

169. Ya.G. Avdeev, O.A. Kireeva, D.S. Kuznetsov and Yu.I. Kuznetsov, The Influence of Hexamethylenetetramine on the Corrosion Inhibition of Low Carbon Steel in Mixtures of Sulfurous and Phosphorus Acids Containing Fe(III) by IFKhAN-92 and KNCS Composition, Prot. Met. Phys. Chem. Surf., 2018, 54, no. 7, 1298-1304. doi: 10.1134/S2070205118070055

170. Ya.G. Avdeev, O.A. Kireeva, D.S. Kuznetsov and Yu.I. Kuznetsov, Usilenie urotropinom ingibirovaniya korrozii stali 08PS kompozitsiyey IFKhAN-92 s KNCS v smesyakh $\mathrm{HCl} \mathrm{i} \mathrm{H}_{3} \mathrm{PO}_{4}$, soderzhashchikh $\mathrm{Fe}$ (III) (Improving the inhibition of 08PS steel corrosion in $\mathrm{HCl}$ and $\mathrm{H}_{3} \mathrm{PO}_{4}$ by mixtures containing $\mathrm{Fe}(\mathrm{III})$ by IFhAN-92 and KNCS using urotropine additive), Korroz.: mater., zashch. (Corrosion: materials, protection), 2018, no. 7, 22-28 (in Russian). doi: 10.31044/1813-7016-2018-0-7-22-28 